\title{
Aftertreatment Technologies for Diesel Engines: An Overview of the Combined Systems
}

\author{
Ferenc Martinovic ${ }^{1}$, Lidia Castoldi ${ }^{2}$ (D) and Fabio Alessandro Deorsola ${ }^{1, *(D)}$ \\ 1 Department of Applied Science and Technology, Politecnico di Torino, C.so Duca degli Abruzzi 24, \\ 10129 Turin, Italy; ferenc.martinovic@polito.it \\ 2 Department of Energy, Politecnico di Milano, Via La Masa 34, 20156 Milano, Italy; lidia.castoldi@polimi.it \\ * Correspondence: fabio.deorsola@polito.it; Tel.: +39-011-090-4662
}

Citation: Martinovic, F.; Castoldi, L.; Deorsola, F.A. Aftertreatment Technologies for Diesel Engines: An Overview of the Combined Systems. Catalysts 2021, 11, 653. https:// doi.org/10.3390/catal11060653

Academic Editor:

Anne Giroir-Fendler

Received: 20 April 2021

Accepted: 19 May 2021

Published: 21 May 2021

Publisher's Note: MDPI stays neutral with regard to jurisdictional claims in published maps and institutional affiliations.

Copyright: (c) 2021 by the authors. Licensee MDPI, Basel, Switzerland. This article is an open access article distributed under the terms and conditions of the Creative Commons Attribution (CC BY) license (https:// creativecommons.org/licenses/by/ $4.0 /)$.

\begin{abstract}
The abatement of the pollutants deriving from diesel engines in the vehicle sector still represents an interesting scientific and technological challenge due to increasingly limiting regulations. Meeting the stringent limits of $\mathrm{NO}_{\mathrm{x}}$ and soot emissions requires a catalytic system with great complexity, size of units, and number of units, as well as increased fuel consumption. Thus, an after-treatment device for a diesel vehicle requires the use of an integrated catalyst technology for a reduction in the individual emissions of exhaust gas. The representative technologies devoted to the reduction of $\mathrm{NO}_{x}$ under lean-burn operation conditions are selective catalytic reduction (SCR) and the lean $\mathrm{NO}_{\mathrm{x}}$ trap (LNT), while soot removal is mainly performed by filters (DPF). These devices are normally used in sequence, or a combination of them has been proposed to overcome the drawbacks of the individual devices. This review summarizes the current state of $\mathrm{NO}_{\mathrm{x}}$ and soot abatement strategies. The main focus of this review is on combined technologies for $\mathrm{NO}_{\mathrm{x}}$ removal (i.e., LNT-SCR) and for the simultaneous removal of $\mathrm{NO}_{x}$ and soot, like SCR-on-Filter (SCRoF), in series LNT/DPF and SCR/DPF, and LNT/DPF and SCR/DPF hybrid systems.
\end{abstract}

Keywords: soot abatement; $\mathrm{NO}_{\mathrm{x}}$ abatement; SCR; SCRoF; LNT; LNT/SCR; combined technique

\section{Introduction}

Air pollution is the result of a combustion process of hydrocarbon fuels that besides $\mathrm{CO}_{2}$ and $\mathrm{H}_{2} \mathrm{O}$ produces a large variety of other pollutants. For this reason, we have observed the excessive emission of certain substances into the atmosphere, causing changes to the air's natural properties that could have harmful effects on living beings and ecosystems. Atmospheric pollution is one of the most important environmental risks to human health $[1,2]$, and it is therefore an issue that should be urgently addressed. The main causes of air pollution are linked to anthropogenic activities, like energy production, household heating, transport, industrial activities, agriculture, and waste treatment, and for these reasons, the most affected regions are the large urban areas.

In the transport sector, the main pollutants to be considered are $\mathrm{NO}_{\mathrm{x}}, \mathrm{CO}, \mathrm{HC}$, smoke (particulate matter: $\mathrm{PM}$ ). $\mathrm{NO}_{\mathrm{x}}$ is formed when air is heated to very high temperatures; the most prevalent $\mathrm{NO}_{\mathrm{x}}$ species from engines is $\mathrm{NO}$, which subsequently oxidizes in the atmosphere to form $\mathrm{NO}_{2}$ and also reacts with most hydrocarbons to form ozone; both ozone and $\mathrm{NO}_{2}$ are strong, toxic oxidants. Thus, $\mathrm{NO}_{x}$ is a criteria pollutant that is regulated. Additionally, PM is mainly composed of soot, which is produced during the incomplete combustion of fuel at high temperatures; those fine particles are suspected to be involved in the development of cancer, as well as cardiovascular and respiratory health effects.

For these reasons, worldwide restrictive emission limits have been imposed by the Environmental Protection Agency (EPA), working mainly in USA, and the European Parliament (EURO), operating in Europe. Moreover, new emission evaluation test procedures, like WLTP (Worldwide harmonized Light Vehicles Test Procedure), RDE (Real Driving 
Emissions) and PEMS (portable emissions measurement system), have been implemented to more realistically reflect driving emissions [3-6].

Other countries have adopted their own emission regulations, often synchronized with other regulations for market compatibility. The recent China 6 emission limits are, in some aspects, even more stringent than the EURO and EPA limits as a consequence of recent efforts to improve urban air quality. Future limits that are expected to be implemented are setting the not-to-exceed limit of particulate number to $3 \times 10^{11}$ and limiting the emissions of $\mathrm{NH}_{3}$ and $\mathrm{N}_{2} \mathrm{O}$ that are currently not regulated. $\mathrm{NH}_{3}$ is generally dosed in excess for the better performance of the $\mathrm{NO}_{\mathrm{x}} \mathrm{SCR}$ reaction, but this leads to $\mathrm{NH}$-slip. The outlet $\mathrm{NH}_{3}$ concentration is difficult to measure due to the cross sensitivity of detectors for $\mathrm{NO}_{\mathrm{x}}$ and $\mathrm{H}_{2} \mathrm{O}$ vapor. A common method to reduce $\mathrm{NH}_{3}$ emissions is to install an ammonia slip catalyst that has the issue of non-selective oxidation to yield $\mathrm{NO}_{x}$ and $\mathrm{N}_{2} \mathrm{O}$. The control of these pollutants requires the multiscale and integrated design of novel catalyst formulations and engineering solutions for the monolith and aftertreatment configuration [7-11].

In order to meet so stringent emission regulations, suitable technologies-both directly manipulating engine operating characteristics (so-called primary methods) and adding catalytic after-treatment systems (namely secondary techniques) - must be developed. Current commercial solutions combine a diesel oxidation catalyst (DOC) for the removal of $\mathrm{CO}$ and hydrocarbons, a catalyzed diesel particulate filter (CDPF) for soot filtration, and a Lean $\mathrm{NO}_{\mathrm{x}}$ Trap (LNT) or a selective catalytic reduction (SCR) step to remove $\mathrm{NO}_{\mathrm{x}}$. These operations are carried out in different compartments, thereby increasing the size and cost of this technology. Consequently, there is significant incentive to develop novel approaches that rely on more abundant elements and combine one or more pollutant conversion steps [12].

LNT and SCR are two contenders for the abatement of $\mathrm{NO}_{\mathrm{x}}$ from mobile sources under lean conditions [13-17]. LNT technology is generally applied to light vehicles, whereas SCR is preferred in heavy-duty vehicles where the presence of the complex urea dosing system is not a concern $[18,19]$. The basic principle of LNT technology is a cycle composed of two phases: a first, longer lean phase (30-90 s), in which gaseous $\mathrm{NO}_{\mathrm{x}}$ is trapped and stored on a suitable catalyst, and a second, shorter rich phase (3-5s) that activates the release of stored $\mathrm{NO}_{x}$ and its reduction to, theoretically, $\mathrm{N}_{2}$. Specifically, a typical LNT catalyst is composed of a noble metal (usually $\mathrm{Pt}$, but also $\mathrm{Pd}$ and $\mathrm{Rh}$ ) to activate the oxidation/reduction of $\mathrm{NO}_{\mathrm{x}}$ and an alkali earth metal (usually $\mathrm{Ba}$ and/or $\mathrm{K}$ ) to store $\mathrm{NO}_{\mathrm{x}}$ as nitrites or nitrates. In contrast to the cyclic nature of LNTs, SCR continuously functions and utilizes ammonia $\left(\mathrm{NH}_{3}\right)$ as the reductant to selectively reduce $\mathrm{NO}_{\mathrm{x}}$ on a zeolite-based catalyst doped with Fe and/or $\mathrm{Cu}$. However, for safety reasons, instead of ammonia, an aqueous solution of urea (AdBlue ${ }^{\circledR}$ ) that is thermally decomposed at the operative temperature of the catalyst to yield ammonia is used.

A diesel particulate filter (DPF) is an exhaust gas after-treatment device that is present on all Euro 4 and later diesel cars. It is a filter that captures and stores exhaust soot (some refer to them as soot traps) in order to reduce emissions from diesel cars. DPF operations and drawbacks are addressed in the next section.

To overcome $\mathrm{NO}_{x}$ and soot reduction imposed by upcoming emission regulations, any $\mathrm{NO}_{x}$ aftertreatment system has to be considered in combination with a DPF that can be placed up- or down-stream an $\mathrm{NO}_{x}$ aftertreatment unit. Indeed, advanced combined systems could offer the best performances due to the benefit of synergistic effects. For this purpose, technologies like combined LNT/SCR, SCR-on-Filter (SCRoF), and combined DPF-LNT/SCR systems have been proposed in different layouts with the aim to overcome the drawbacks of individual devices. This review provides an overview of the main results reported on these combined systems and current research directions. 


\section{Diesel Particulate Filter (DPF), Catalytic Particulate Filter (CDPF), and SCR-on-DPF (SCRoF)}

\subsection{DPF and CDPF}

The function of a DPF is to trap particulate matter and soot before they are released into the atmosphere; its removal efficiency is normally near $85 \%$. Cordierite $2 \mathrm{MgO}-2 \mathrm{Al}_{2} \mathrm{O}_{3}-$ $5 \mathrm{SiO}_{2}$ ) or silicon carbide $(\mathrm{SiC})$ are used to obtain the wall-flow monolith; the honeycomb structure is characterized by channels alternatively that are closed at the end (Figure 1).

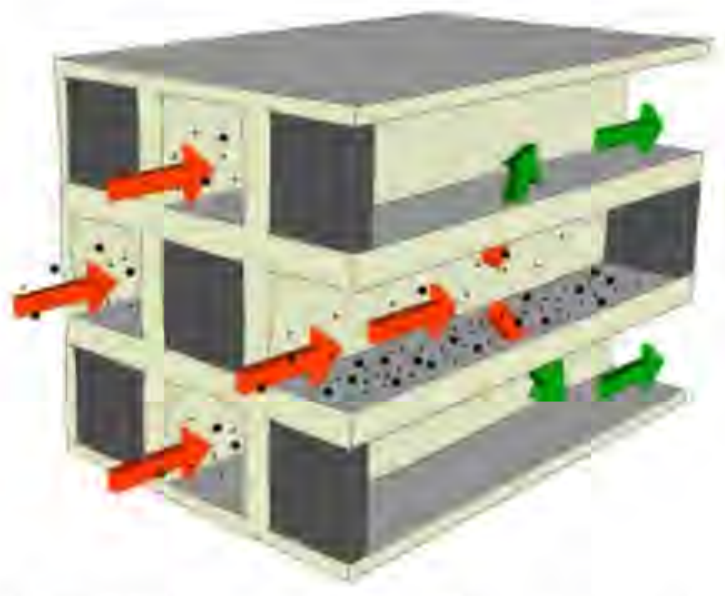

Figure 1. Scheme of a wall-flow particulate filter. Reprinted with permission from ref. [20]. Copyright 2017 Elsevier.

The exhausts gases pass through the porous wall of the DPF, while PM remains trapped into the channels; the particles create a barrier to the flow gas, causing an increase in the pressure drop (and as consequence a decrease in the engine efficiency). For this reason, the DPF need to be periodically regenerated. The regeneration could be passive or active. In the first case, $\mathrm{PM}$ is oxidized to $\mathrm{CO}_{2}$ at temperatures above $250{ }^{\circ} \mathrm{C}$, with $\mathrm{NO}_{2}$ as the oxidant (Reactions (1) and (2)), while in the latter the oxidation occurs at high temperature, above $500{ }^{\circ} \mathrm{C}$ with $\mathrm{O}_{2}$ as the oxidant (Reactions (3)-(4)) [21]. It is worth noting that the active regeneration implies a fuel penalty to reach those exhaust temperatures.

$$
\begin{gathered}
\mathrm{C}+2 \mathrm{NO}_{2} \rightarrow 2 \mathrm{NO}+\mathrm{CO}_{2} \\
\mathrm{C}+\mathrm{NO}_{2} \rightarrow \mathrm{NO}+\mathrm{CO} \\
\mathrm{C}+\mathrm{O}_{2} \rightarrow \mathrm{CO}_{2} \\
\mathrm{C}+1 / 2 \mathrm{O}_{2} \rightarrow \mathrm{CO}
\end{gathered}
$$

As previously reported, Reactions (1) and (2) occur at low temperatures, near $250^{\circ} \mathrm{C}$, using $\mathrm{NO}_{2}$ and forming $\mathrm{NO}$, which is in turn reoxidized to $\mathrm{NO}_{2}$ in the upstream DOC or over a CDPF coated with a Pt-based oxidation catalyst. In this last case, thanks to the formation of $\mathrm{NO}_{2}$, a continuous regeneration of the CDPF is achieved, thus reducing the necessity to increase the temperature for active regeneration Moreover, the presence of an oxidation catalyst permits the conversion of $\mathrm{CO}$ (Reactions (2) and (4)) into $\mathrm{CO}_{2}$.

\subsection{Integrated NOx-SCR on Diesel Particulate Filter (SCRoF)}

One effective way to reduce all four major pollutants from a diesel engine is to combine DPF and SCR systems; indeed, with this configuration, all gaseous and particulate emissions are reduced (by 70\% or more), and the most stringent (future) emission legislation can usually be met. Technical options include coating a DPF with an SCR-catalyst to obtain a single device called an SCR-on-Filter (SCRoF or DPF/SCR), thereby performing both $\mathrm{NO}_{\mathrm{x}}$ reduction and filtration. This is achieved by plugging a monolith on alternating 
ends (chessboard pattern), thus forcing gas through the pores and performing filtration (Figure 1). Simultaneously, $\mathrm{NO}_{\mathrm{x}}$ is reduced by the SCR catalyst deposited inside the pores, with loading typically between 60 and $180 \mathrm{~g}_{\mathrm{cat}} / \mathrm{L}$. $\mathrm{NO}_{\mathrm{x}}$ is reduced both while passing through the pores of the monolith and while flowing downstream towards the exit. The main advantage is the reduction of size and cost; moreover, the correct position close to the engine permits the achievement of a higher operating temperature and, consequently, better performances [22].

The SCRoF configuration can be applied to both light-duty diesel (LDD) and heavyduty diesel (HDD) vehicles, but it is more suited for LDD [23-26]. The HDD configuration operates at higher temperatures, usually between 250 and $400{ }^{\circ} \mathrm{C}$, and can rely on the $\mathrm{NO}_{2}$-mediated passive soot oxidation taking place over the CDPF. Passive soot oxidation is not common in LDD due to lower operation temperatures, between 200 and $300{ }^{\circ} \mathrm{C}$, and the DPF is normally regenerated by raising the temperature to above $600^{\circ} \mathrm{C}$ and maintaining it for 10-30 min via fuel injected over the DOC. Since only a small fraction of $\mathrm{NO}_{2}$ over the SCRoF can be utilized for soot oxidation (see the discussion below), the main available oxidant is $\mathrm{O}_{2}$ and active regeneration, like that for LDD, is required. By placing the SCRoF closer to the engine outlet, the aftertreatment device heats up faster and therefore reduces the cold start emissions more than a decoupled CDPF-SCR system [23-26]. This is of special importance in LDD applications, since most pollutants are emitted in the first minutes after the engine starts, when the temperature is too low $\left(<180^{\circ} \mathrm{C}\right)$ for the proper operation of the aftertreatment device.

The soot filtration in SCRoF involves complex and multistage phenomena. Soot accumulation is accompanied by an increase in the resistance to flow, resulting in an increased pressure drop. The porosity of the filter and the distribution of the SCR catalyst are of paramount importance and, as is shown below, zoned and engineered SCR catalyst coatings can have a high impact on filtration and regeneration performance. A filter characterized by a high porosity decreases the inherent pressure drop and can mitigate soot buildup by enhancing flow and accommodating higher amounts of soot. The porosity of a common SCRoF comprised of $\mathrm{SiC}$ is typically $55-60 \%$, with a median pore width of approximately $20 \mu \mathrm{m}[20,24,27]$. The deposition of the SCR catalyst decreases the porosity but does not change the median pore size (Figure 2) $[20,24,27]$. The pressure drop is not linearly related to the filtered soot, and two different filtration mechanisms can be clearly distinguished by the presence of a knee in the filtration curve (vide infra). In the first stage, the soot is retained in the pores of the monolith, which blocks the gas flow and throat pores. Accordingly, the rate of the increase of the pressure drop per amount of filtered soot is the highest in the initial stage. Following this relatively short stage, the filtration changes to cake filtration, with a slower increase in the pressure drop per accumulated soot [24]. The soot in the filtration cake can detach from the monolith wall under certain conditions and form solid plugs that have detrimental effects on the pressure drop. Since these phenomena are largely unpredictable and the exact conditions under which they arise are unknown, the proper control and identification of indicator parameters for triggering an active regeneration system are challenging [28]. 


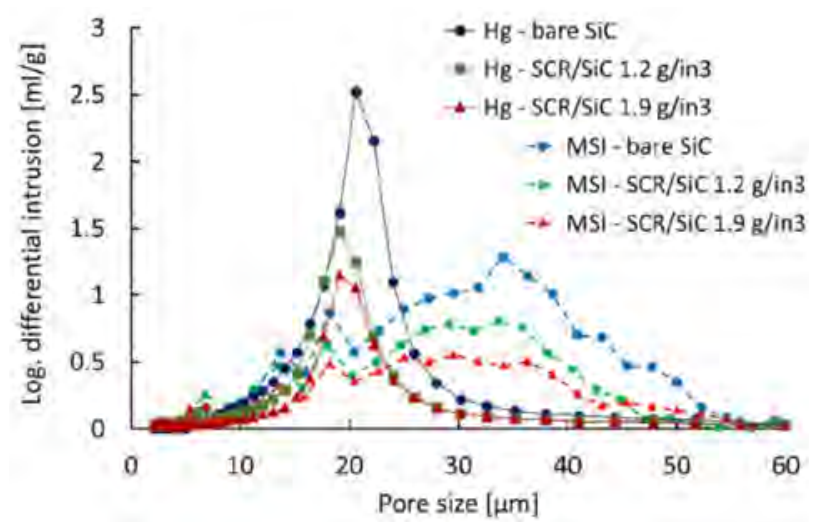

Figure 2. Pore size distribution over a bare SiC substrate and catalyst loaded SCRoF-comparison of MSI/XRT and Hg porosimetry. Reprinted with permission from ref. [20]. Copyright 2017 Elsevier.

\section{SCR Catalysts for SCRoF}

The state-of-the-art catalyst used for SCRoF application is $\mathrm{Cu}$-exchanged small pore zeolite, mainly with a chabazite (CHA) structure. Compared to the larger-pore BEA- or MFI-structured ZSM-5 zeolites, the CHA-based zeolites were revolutionary in terms of activity, hydrothermal stability, and resistance to poisoning. The $\mathrm{CHA}$ zeolite structure and ion-exchanged $\mathrm{Cu}$ are stable up to $750{ }^{\circ} \mathrm{C}$ and start deteriorating at $800{ }^{\circ} \mathrm{C}$. With BEA- and ZSM-5-based Cu zeolites, SCR activity is severely reduced after ageing at $650{ }^{\circ} \mathrm{C}$ due to the collapse of the zeolite structure accompanied by the formation of $\mathrm{CuAl}_{2} \mathrm{O}_{4}$ spinels and extra framework $\mathrm{CuO}$. Cu-SAPO-34 and $\mathrm{Cu}-\mathrm{SSZ}-13$ can achieve higher $\mathrm{NO}_{\mathrm{x}}$ conversion rates, generally in the order SSZ-13 = SAPO-34 > ZSM-5 > BEA [29-32]. Extensive spectroscopic and reactivity characterizations of the $\mathrm{Cu}-\mathrm{CHA}$ SCR catalysts have demonstrated the importance of small zeolite pores, especially for SCRoF applications where high hydrothermal stability is of paramount importance. The eight-member ring pores of SSZ-13 could prevent dealumination and then stabilize $\mathrm{Cu}$ and $\mathrm{NH}_{4} \mathrm{NO}_{3}$ that reduce $\mathrm{N}_{2} \mathrm{O}$ emissions. These considerations led to the development of different zeolite synthesis techniques like synthesis in $\mathrm{F}^{-}$media and through various structure-directing agents or seeding methods. Other small-pore zeolite topologies have been developed, with the two most promising synthesized being Cu-SSZ-39 (with AIE structure) and the high silica $\mathrm{Cu}$-LTA. For these materials, data relative to reactivity, hydrothermal stability, and characterization are available, but no data are available regarding their practical implementation [33-37].

The mechanism of the SCR reaction over $\mathrm{Cu}$ zeolites is disputed in the literature, and different reaction pathways have been proposed. No single unified mechanism exists, and it appears that the SCR mechanism changes with zeolite structure, Cu loading, and temperature region [32,38-40]. For Cu-SSZ-13, spectroscopic evidence suggests the formation of a $\mathrm{Cu}\left(\mathrm{NH}_{4}\right)_{2}$ complex at a low temperature $\left(<300^{\circ} \mathrm{C}\right)$ that is active for $\mathrm{NO}_{\mathrm{x}}$ reduction. Ammonia and $\mathrm{NO}_{x}$ complexes are coordinated on the same $\mathrm{Cu}$ site and form an intermediate that is commonly identified as $\mathrm{HONO}$ and that decomposes to $\mathrm{N}_{2}$ and $\mathrm{H}_{2} \mathrm{O}$. $\mathrm{Cu}^{2+}$ behaves as an atomic single site during the $\mathrm{NO}_{x}$ reduction phase $\left(\mathrm{Cu}^{2+} \rightarrow \mathrm{Cu}^{+}\right)$, as evidenced by the linear correlation between the number of sites and TOF. The reoxidation of $\mathrm{Cu}^{+}$to $\mathrm{Cu}^{2+}$ by $\mathrm{O}_{2}$ does not show such linear correlation, and $\mathrm{Cu}^{+}-\mathrm{O}_{2}-\mathrm{Cu}^{+}$dimers and other oligomers have been suggested. This implies the migration to $\mathrm{Cu}$ atoms between the zeolite cage and the continuous dispersion/aggregation of the active sites [32,38-40].

Other than $\mathrm{Cu}$ and $\mathrm{Fe}-\mathrm{CHA}, \mathrm{V}_{2} \mathrm{O}_{5}-\mathrm{WO}_{3} / \mathrm{TiO}_{2}$ (VWT systems) has been suggested for SCRoF applications, noting the slight activity of $\mathrm{V}$ towards soot oxidation. The low thermal stability and irreversible deactivation of VWT catalysts above $450{ }^{\circ} \mathrm{C}$ due to sintering and phase transition can be cited as their main drawbacks, making their practical application questionable [41-43]. 


\subsection{Main Challenges of the SCRoF Concept and Solutions}

\subsubsection{Impact of SCR Reaction on Soot Oxidation}

The main disadvantage of the SCRoF configuration is the limited availability of $\mathrm{NO}_{2}$, a key reactant that is essential for both the low-temperature soot oxidation and Fast-SCR pathways, that can be represented by the overall reactions:

$$
\begin{gathered}
\mathrm{NO}+\mathrm{NO}_{2}+2 \mathrm{NH}_{3} \rightarrow 2 \mathrm{~N}_{2}+3 \mathrm{H}_{2} \mathrm{O} \\
\mathrm{C}+\mathrm{NO}_{2}+\mathrm{O}_{2} \rightarrow \mathrm{NO}+\mathrm{CO}_{2}+\mathrm{CO} \\
4 \mathrm{NO}+4 \mathrm{NH}_{3}+\mathrm{O}_{2} \rightarrow 4 \mathrm{~N}_{2}+6 \mathrm{H}_{2} \mathrm{O} \\
4 \mathrm{NO}_{2}+4 \mathrm{NH}_{3} \rightarrow 6 \mathrm{H}_{2} \mathrm{O}+4 \mathrm{~N}_{2}+\mathrm{O}_{2}
\end{gathered}
$$

where Reaction (5) is known as Fast-SCR, Reaction (7) is known as Standard SCR, Reaction (8) is known as $\mathrm{NO}_{2}-\mathrm{SCR}$, and Reaction (6) represents the soot oxidation mediated by $\mathrm{NO}_{2}$. Among the three principal types of SCR reactions, the Fast-SCR is kinetically fastest and takes place prior the transition to Standard SCR when $\mathrm{NO}_{2} / \mathrm{NO}_{\mathrm{x}}<0.5$ (when $\mathrm{NO}_{2}$ is depleted) or $\mathrm{NO}_{2}-\mathrm{SCR}$ when $\mathrm{NO}_{2} / \mathrm{NO}_{\mathrm{x}}>0.5$ (when $\mathrm{NO}$ is depleted).

The CDPF performs passive soot oxidation by reoxidizing the NO produced during the R2 several times, which is obviously not an option in the SCRoF, where high $\mathrm{NO}_{\mathrm{x}}$ conversion is the main purpose. The inhibiting effect of the SCR reaction on soot oxidation has been studied in detail in several reports [22,24,44-48]. A representative example, which utilized a Cu-based zeolite as the SCR catalyst, can be found in Figure 3. In a case without $\mathrm{NO}_{x}$ in the reaction stream (meaning no SCR reaction), soot oxidation was similar to the case of soot oxidation with $\mathrm{O}_{2}$, meaning that $\mathrm{NH}_{3}$ had no significant effect on the soot oxidation activity. When $\mathrm{NO}_{x}$ with different $\mathrm{NO}_{2} / \mathrm{NO}_{x}$ ratios was included in the SCR reaction, soot oxidation differed based on the ratio, with the best results obtained with the highest proportion of $\mathrm{NO}_{2}$ in the reaction mixture [44]. However even in the case when $\mathrm{NO}_{2} / \mathrm{NO}_{\mathrm{x}}$ was 1 , which is impossible in practical circumstances, the contribution of $\mathrm{NO}_{2}$ to soot oxidation was limited and the peak soot oxidation temperature did not change.
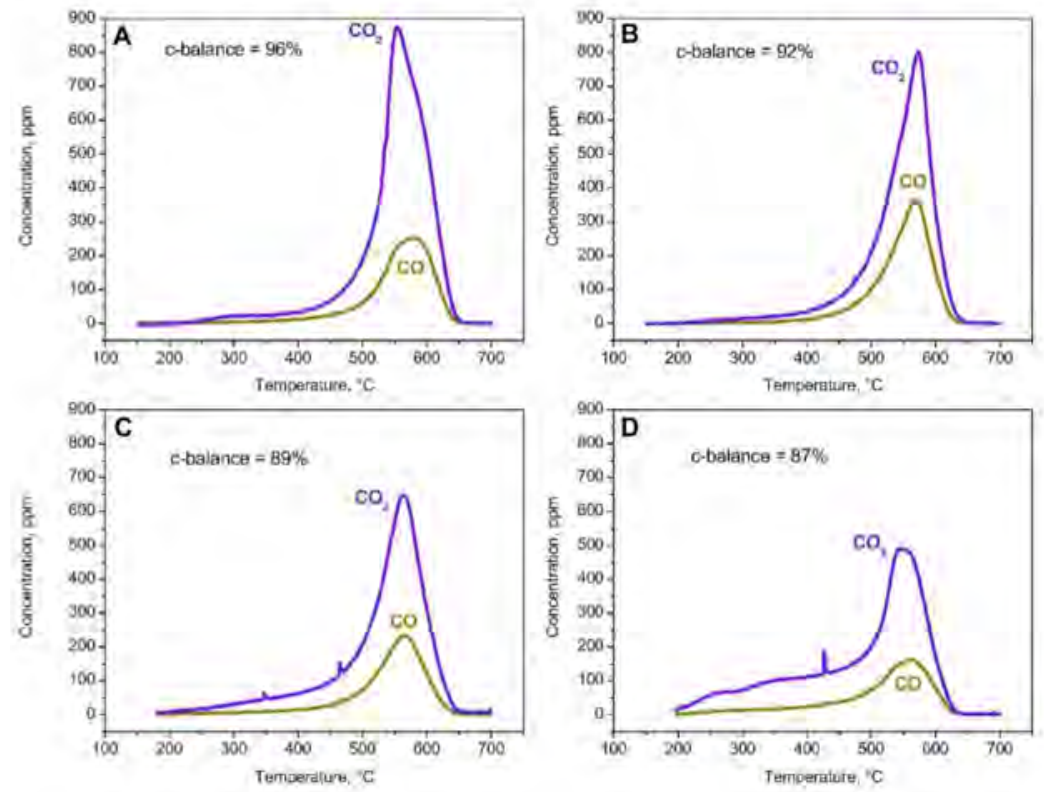

Figure 3. PrintexU combustion runs under SCR reacting conditions. Flow rate $=172 \mathrm{~cm}^{3} / \mathrm{min}(\mathrm{STP})$; feed: $\mathrm{H}_{2} \mathrm{O}=5 \%(v / v) ; \mathrm{O}_{2}=8 \%(v / v)$; and $\mathrm{NH}_{3}=500$ ppm. (A) $\mathrm{NO}_{\mathrm{x}}=0$ ppm. (B) $\mathrm{NO}_{\mathrm{x}}=500$ ppm; $\mathrm{NO}_{2} / \mathrm{NO}_{\mathrm{x}}=0$. (C) $\mathrm{NO}_{\mathrm{x}}=500 \mathrm{ppm} ; \mathrm{NO}_{2} / \mathrm{NO}_{\mathrm{x}}=0.5$. (D) $\mathrm{NO}_{\mathrm{x}}=500 \mathrm{ppm} ; \mathrm{NO}_{2} / \mathrm{NO}_{\mathrm{x}}=1$. Reprinted with permission from ref. [44]. Copyright 2016 Elsevier. 
In a study by Rappe [24], this was demonstrated through the temperature required to regenerate the pressure drop over the filter (Figure 4). The filter could be regenerated at the lowest temperature when $\mathrm{NH}_{3}$ was excluded from the reaction steam, while in the cases where $\mathrm{NH}_{3}$ was included and an SCR reaction took place, the regeneration temperature was shifted by more than $70{ }^{\circ} \mathrm{C}$ to higher temperatures. In the presence of $\mathrm{NH}_{3}$, the regeneration performance was mostly dependent on the $\mathrm{NO}_{2} / \mathrm{NO}_{\mathrm{x}}$ ratio, with higher ratios resulting in better soot oxidation. This inhibition was also demonstrated in several papers over powdered SCR catalyst-soot mixtures. In all cases, the same conclusion was reached: in the presence of the SCR reaction, the passive soot oxidation was hindered because the oxidant available for the soot oxidation was $\mathrm{O}_{2}$ and not $\mathrm{NO}_{2}$ [22,24,44-48].

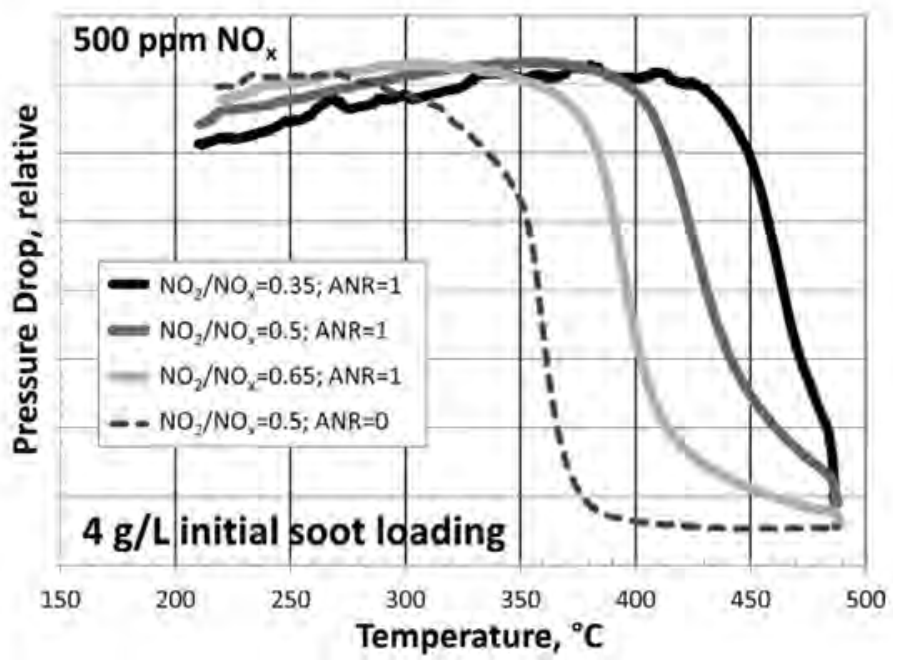

Figure 4. TPO of SCR/DPF (SCRoF) with $4 \mathrm{~g} / \mathrm{L}$ of initial soot loading displayed as the relative pressure drop versus temperature with the SCR reaction with $500 \mathrm{ppm}$ of $\mathrm{NO}_{x}$ at $\mathrm{NO}_{2} / \mathrm{NO}_{x}=0.35$, 0.5 , and 0.65 and $\mathrm{NH}_{3} / \mathrm{NO}_{x}=1$, compared with $\mathrm{NO}_{2} / \mathrm{NO}_{x}=0.5$ without $\mathrm{SCR}\left(\mathrm{NH}_{3} / \mathrm{NO}_{x}=0\right)$. Reprinted with permission from ref. [24]. Copyright 2014 American Chemical Society.

\subsubsection{Proposed Solutions}

One of the earliest solutions proposed for solving the issue of rapid soot accumulation was the zoning of the SCR catalyst by targeted coating, with the aim to increase the distance between the SCR catalyst and the soot, thereby decoupling the competing reactions to an extent. The SCR catalyst can be preferentially coated on the downstream section of the monolith on the outlet side of the wall. The improvement of soot oxidation over the SCRoF in such a zoned configuration has been investigated by several authors, and representative results are shown in Figures 5-8. Compared to uniform coating, in the case when the SCR catalyst was coated predominantly downstream, both the pore plugging and cake filtration stages of the soot accumulation were delayed and a higher soot filtration capacity was achieved. Since the total SCR catalyst loading was the same- $120 \mathrm{~g} / \mathrm{L}$ for the uniform coating and 90-150 g/L for the two-zone configuration-the outlet $\mathrm{NO}_{\mathrm{x}}$ conversion was the same. Indeed, when a real SCRoF system was analyzed by element mapping, three distinct SCR coating zones were identified (Figure 6): an inlet zone that was lightly coated, a second zone with dense coating, and a medium coated downstream part [49]. In all the cases, the purpose of the zoning was to delay the SCR reaction, thereby allowing the remaining fraction of $\mathrm{NO}_{\mathrm{x}}$ to react with the soot. 

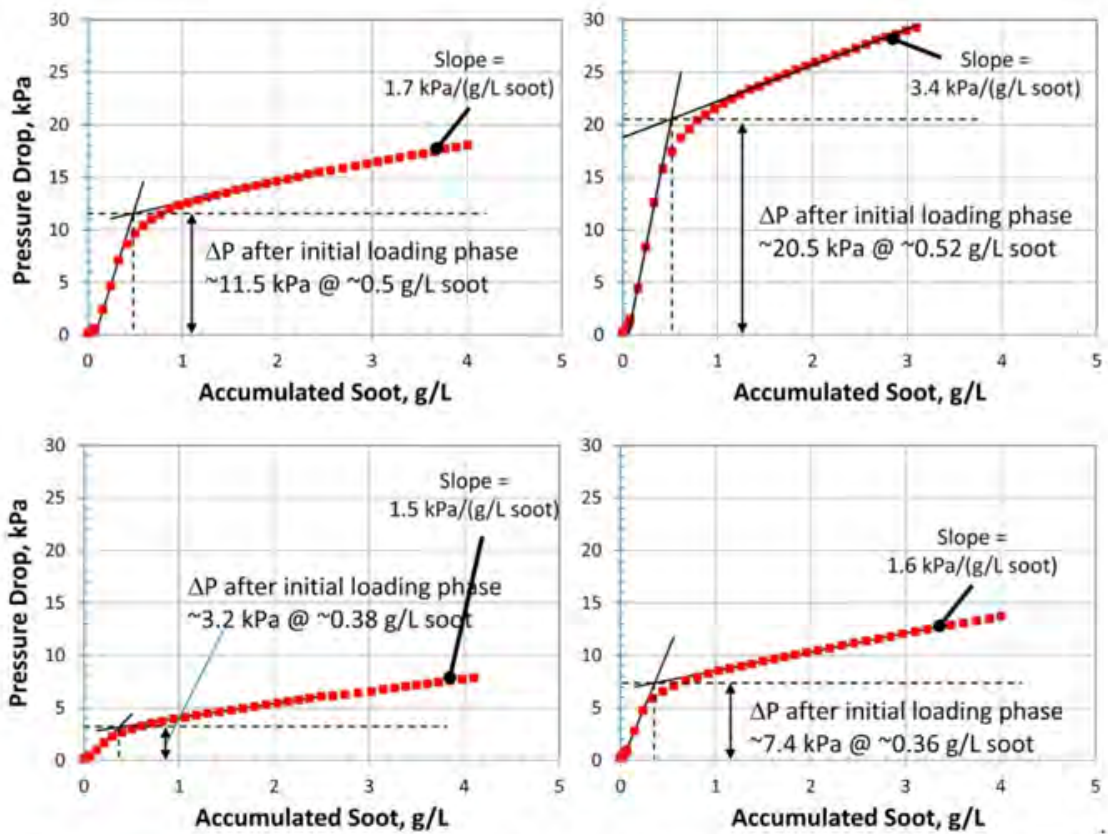

Figure 5. Soot-loading characteristics of 90 (left) and $150 \mathrm{~g} / \mathrm{L}$ (right) SCR/DPF samples configured such that the catalyst was predominantly present on the upstream and inlet channel wall (top) or the downstream and outlet channel wall (bottom) portion of the filter. Reprinted with permission from ref. [24]. Copyright 2014 American Chemical Society.

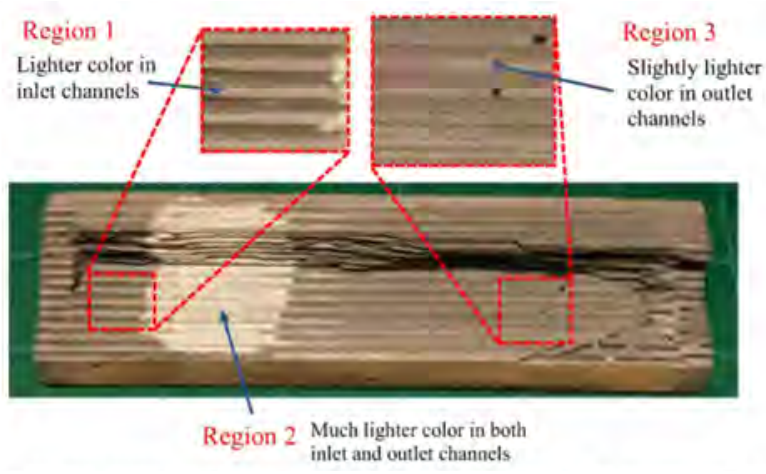

Figure 6. Zoned catalyst coating of SCRoF. Reprinted with permission from ref. [49]. Copyright 2018 Springer Nature.

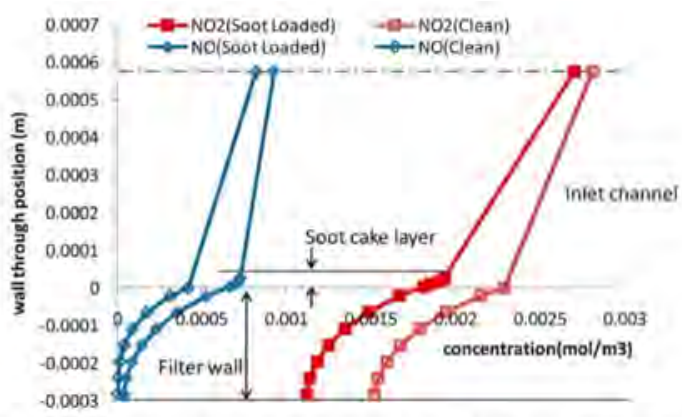

Figure 7. Concentration distribution of $\mathrm{NO}_{\mathrm{x}}$ through the wall and soot cake layers for an $\mathrm{NO}_{2} / \mathrm{NO}_{\mathrm{x}}$ ratio of 0.75 measured at the front end. The center line represents the center of the inlet channel. Reprinted with permission from ref. [47]. Copyright 2012 American Chemical Society. 

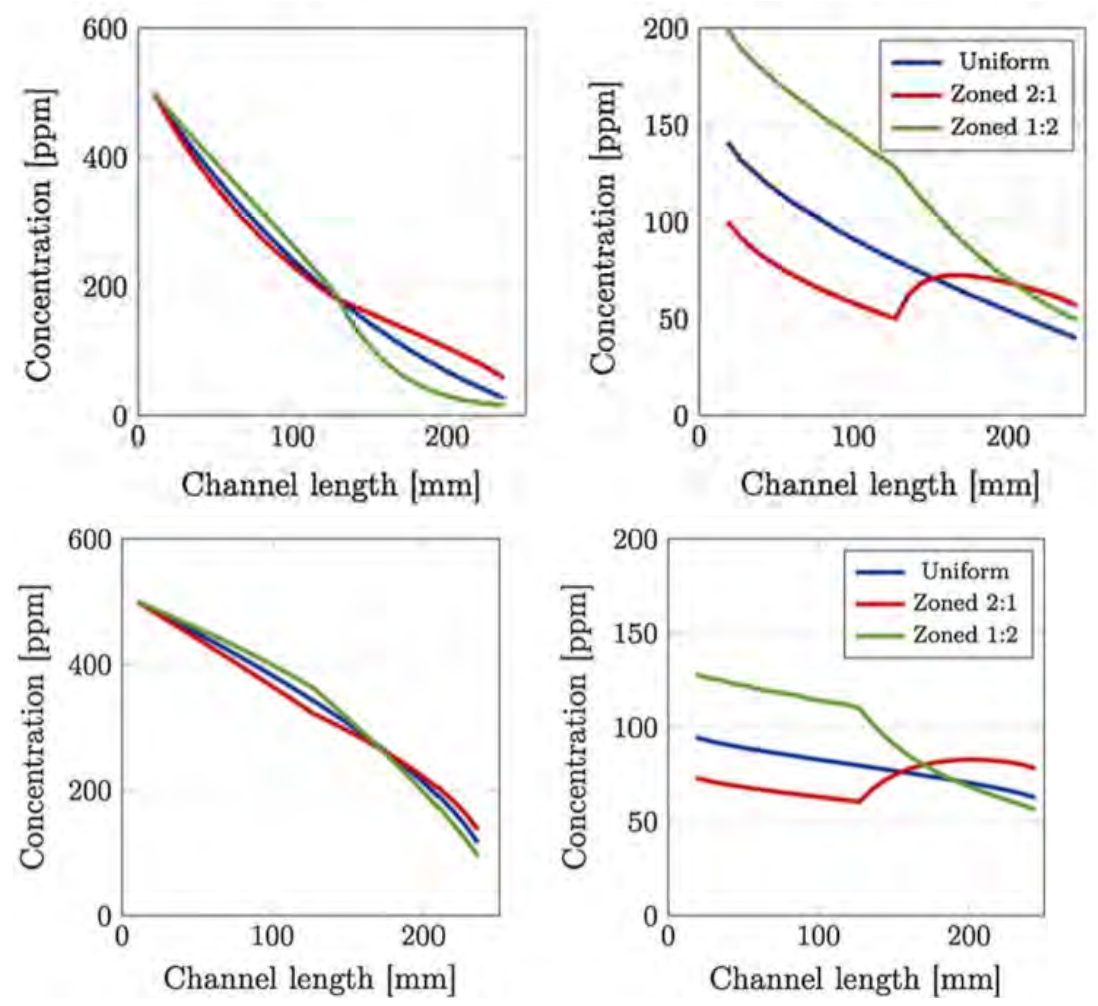

Figure 8. Comparison of (left) inlet and (right) outlet channel $\mathrm{NO}_{\mathrm{x}}$ concentration profiles, at $250{ }^{\circ} \mathrm{C}$, between uniformly- and zone-coated SCR/DPF without soot (top) and with $4 \mathrm{~g} / \mathrm{L}$ of soot loaded (bottom) SCRoF. Reprinted with permission from ref. [48]. Copyright 2017 Elsevier.

Only the outlet conditions can be monitored experimentally, and several simulation studies have been published to better understand the phenomena taking place inside the SCRoF $[46-48,50,51]$. These simulations have confirmed the basic conclusions of the experimental results regarding the competitive nature of the SCR reaction and soot oxidation, as well as the depletion of $\mathrm{NO}_{2}$. Models of higher dimensions can give more complete information and capture both the phenomena occurring during the gas flow through the filter wall and during the downstream flow. Park et al. [47] investigated $\mathrm{NO}_{\mathrm{x}}$ concentration through the wall of a filter at different locations (Figure 7). They demonstrated that the soot consumed excess $\mathrm{NO}_{2}$ for the production of $\mathrm{NO}$ when $\mathrm{NO}_{2} / \mathrm{NO}_{\mathrm{x}}>0.5$ and, interestingly, that the rapid diffusion of $\mathrm{NO}_{2}$ towards the filter occurred, which was the result of the depletion of $\mathrm{NO}_{2}$ by the soot and the larger concentration gradient. This demonstrated that in the filter, both convection and diffusion play significant roles in the transport of gaseous species.

One of the most comprehensive simulations was that of Karamitros et al. [48], which studied the effect of the catalyst zoning, discussed in the previous section. The $\mathrm{NO}_{\mathrm{x}}$ concentration along the gas flow in the SCRoF was greatly impacted by the location of the SCR catalyst, although the overall $\mathrm{NO}_{\mathrm{x}}$ conversion at the outlet was not impacted. As shown in Figure 8, with the downstream deposition of the SCR catalyst, much more $\mathrm{NO}_{\mathrm{x}}$ was available for the soot oxidation than in the case of uniform distribution or upstream deposition. It was furthermore revealed that there are significantly different $\mathrm{NO}_{\mathrm{x}}$ concentrations in the inlet and outlet channels of the filter, and the driving force is the diffusion of $\mathrm{NO}_{2}$ towards the SCR catalyst.

The catalyst coating distribution also influences the distribution of soot in the filter pores and along the monolith, which in turn influences the thermal distribution during regeneration. If the soot loading is too high, the rapid heat release during regeneration can result in filter failure and pore fusion. Of special importance is the soot confined in the monolith pores the can generate local hot-spots with detrimental effects on the nearby catalyst and filter failure. Since the thermal front travels downstream, the largest temperature 
excursion is typically observed at the outlet section of the filter. Methods for avoiding the thermal effect include precisely controlling of the regeneration conditions, like the temperature at which regeneration is triggered, avoiding drop-to-idle during the regeneration, and avoiding the accumulation of too much soot $(<5 \mathrm{~g} / \mathrm{L}$ of soot) $[24,46,52-54]$.

The presence of soot has no significant effect on $\mathrm{NO}_{x}$ conversion; in some papers, no difference was observed, while others noted a slight decrease (approximately $5 \%$ ) in conversion when $\mathrm{NO}_{2} / \mathrm{NO}_{\mathrm{x}}<0.5$; indeed, in the presence of soot, the $\mathrm{NO}_{2} / \mathrm{NO}_{\mathrm{x}}$ ratio decreases, and, in this way, $\mathrm{NO}_{2}$ cannot participate in the Fast SCR reaction. In the case of $\mathrm{NO}_{2} / \mathrm{NO}_{\mathrm{x}}>0.5$, a positive effect of the soot on $\mathrm{NO}_{\mathrm{x}}$ conversion was observed since the soot consumed the excess $\mathrm{NO}_{2}$ and returned the ratio to the ideal of 0.5 .

The two above-mentioned solutions for improving the soot oxidation, i.e., raising the $\mathrm{NO}_{2} / \mathrm{NO}_{\mathrm{x}}$ ratio as high as possible and zoning the SCR catalyst, have synergistic effects. This implies that the DOC preceding the SCRoF needs high PGM loading (and price) to reach an $\mathrm{NO}_{2} / \mathrm{NO}_{x}$ ratio of $>0.5$. This is difficult to achieve, since $\mathrm{NO}_{2}$ formation is suppressed in the presence of $\mathrm{H}_{2} \mathrm{O}$ and unburnt hydrocarbons. Additionally, these solutions do not directly solve the lack of passive regeneration and the issue of accelerated soot deposition over the SCRoF-they merely reduce these effects.

A relatively simple concept involves the addition of a soot oxidation catalyst to the $\mathrm{SCRoF}$, but several challenges must be considered. Some proposals of similar configuration have previously been evaluated, like that of Tang et al., who considered coating the downstream section of the SCRoF with PGM, though without a positive effect since the $\mathrm{NO}_{\mathrm{x}}$ concentration at the $\mathrm{SCRoF}$ outlet was too low to have a meaningful impact on the soot oxidation [23]. A combination of SCR and soot oxidation catalysts was also hypothesized and dismissed by Rappé [24] because of the adverse impact of the oxidation functionality on the reductant usage (i.e., $\mathrm{NH}_{3}$ oxidation).

This highlights one of the main challenges of such a combination, i.e., avoiding the oxidation of $\mathrm{NH}_{3}$ over the soot oxidation catalyst, as well as the associated decrease in $\mathrm{NO}_{\mathrm{x}}$ conversion and $\mathrm{N}_{2} \mathrm{O}$ selectivity. Indeed, it has been shown that $\mathrm{NH}_{3}$ oxidation and $\mathrm{N}_{2} \mathrm{O}$ production are directly correlated with an improvement of soot oxidation activity of the catalyst, meaning that the same active sites are involved for both reactions [55]. Another issue is that the addition of a soot oxidation catalyst could cause an increase of the total catalyst loading, negatively affecting the backpressure.

Martinovic et al. [22,45] recently investigated a potential solution that included a mechanical mixture between a catalyst for soot combustion and an SCR catalyst. It was found that the addition of potassium in small amounts ( $1 \mathrm{wt} \%$ ) over $\mathrm{CeO}_{2}-\mathrm{PrO}_{2}$ (called $\mathrm{KCP}$ ) could selectively poison the acid sites of the soot oxidation catalyst, thereby avoiding $\mathrm{NH}_{3}$ oxidation. The potassium also promoted the soot oxidation activity, further lowering the combustion temperature. Despite the fact that the soot oxidation catalyst was active for $\mathrm{NO}$ oxidation and it enhanced the $\mathrm{NO}_{2}-\mathrm{O}_{2}$-soot reaction with an adjusted $\mathrm{NO}_{2} / \mathrm{NO}_{\mathrm{x}}$ ratio of 0.5 in the gas at the inlet, the contribution of the $\mathrm{NO}_{x}$ to soot oxidation was negligible and soot was oxidized through $\mathrm{O}_{2}$ (Figure 9). In all mechanical mixture cases, the soot combustion temperature was remarkably lower (approximately $150^{\circ} \mathrm{C}$ ) than when only an SCR catalyst was used [22,45]. 


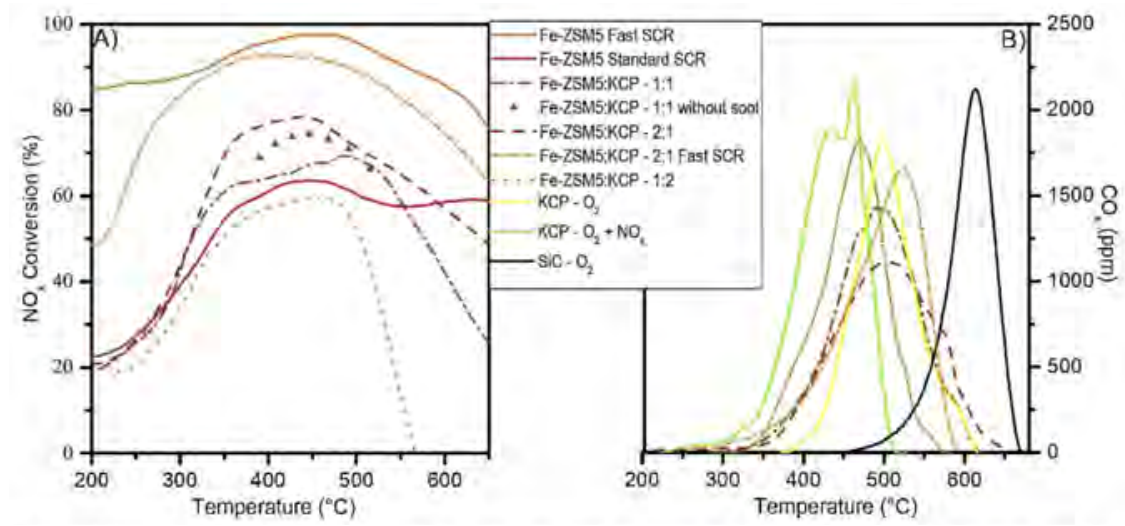

Figure 9. Combined soot oxidation and $\mathrm{NO}_{x} \mathrm{SCR}$ in the physical mixture of KCP and Fe-ZSM-5. Reaction conditions: 500 ppm of $\mathrm{NO}_{\mathrm{x}}, 500 \mathrm{ppm}$ of $\mathrm{NH}_{3}$, and $4 \% \mathrm{O}_{2}$ in $\mathrm{N}_{2} ; \mathrm{NO}_{2} / \mathrm{NO}_{\mathrm{x}}=0$ for standard SCR and 0.5 for fast SCR; $w / f 27 \mathrm{gcat} \cdot \mathrm{s} / \mathrm{L}$; catalyst:soot mass ratio of $9: 1$ in loose contact; $2{ }^{\circ} \mathrm{C} / \mathrm{min}$ heating rate. Reprinted with permission from ref. [22]. Copyright 2020 Elsevier.

If the soot combustion catalyst also acts as an $\mathrm{NO}$ oxidant, it has a great advantage because $\mathrm{NO}_{\mathrm{x}}$ conversion is improved by raising the $\mathrm{NO}_{2} / \mathrm{NO}_{\mathrm{x}}$ ratio and increasing the participation of the Fast SCR regime in the mechanical mixture [22,56-58]. For the FeZSM5:KCP mixture with a mass ratio of $180: 90 \mathrm{mg}$, the $\mathrm{NO}_{\mathrm{x}}$ conversion improved by $20 \%$ when compared to the case when $270 \mathrm{mg}$ of Fe-ZSM5 were used despite the lack of SCR activity for the KCP and the lower amount of SCR catalyst used. When $\mathrm{Cu}$-ZSM5 was used as an SCR catalyst in the case when the inlet $\mathrm{NO}_{2} / \mathrm{NO}_{\mathrm{x}}$ ratio was equal to 0.5 , no improvement in the $\mathrm{NO}_{\mathrm{x}}$ conversion was achieved because, in these cases, the $\mathrm{NO}$ to $\mathrm{NO}_{2}$ oxidation over KCP did not contribute to the Fast SCR reaction (Figure 9) [22].

Another potential solution is to use the same catalyst to perform the soot oxidation and SCR reaction. Surprisingly, little research has been done in this area, but Ce-based catalysts seem promising; indeed, it is well known that they are successfully used in both soot combustion and the SCR reaction, notably Ce-Sn oxides, Ce-Mn oxides, and templated oxides [59-63]. A potential issue with this concept is that none of these catalysts can match the high $\mathrm{NO}_{\mathrm{x}}$ conversion in as wide a temperature range as $\mathrm{Cu}-\mathrm{SSZ}-13$. Furthermore, mixed metal oxides typically undergo deactivation by sintering and phase transition above $600{ }^{\circ} \mathrm{C}$, and they are not resistant to the high temperature hydrothermal conditions of the SCRoF.

\subsubsection{Future Challenges and Developments}

There are several other issues besides accelerated soot accumulation for the SCRoF exacerbated by a close-coupled configuration. The high density of Brønsted acidity and isolated redox metal sites makes the zeolites-based SCR catalysts used with the SCRoF susceptible to hydrocarbon poisoning [64-67]. The influence of hydrocarbons is of special consideration in the SCRoF since, due to close coupling, the SCR catalyst is more exposed to the hydrocarbons present in the exhaust gases than in the separate CDPF and SCR system. Another source of hydrocarbons is diesel soot, which is a mixture of graphitic carbon, $\mathrm{PAH}$, and a wide variety of soluble organic materials. PAH is a liquid and can migrate or evaporate when heated (at approximately $300^{\circ} \mathrm{C}$ ), and it can poison the SCR catalyst deposited in the filter $[65,68,69]$. Larger-pore BEA and ZSM- 5 zeolites strongly deactivate, and $\mathrm{NH}_{3}-\mathrm{SCR}$ is transformed into hydrocarbon-SCR, which is less efficient. The CHA (and MOR) structure offers an enhanced resistance towards hydrocarbon poisoning due to its small pores of $3.8 \AA$ that can provide a barrier to the diffusion of hydrocarbons that have larger kinetic diameters, e.g., $4.3 \AA$ for straight chain alkanes and alkenes. Significant deactivation, an approximately $25-30 \%$ decrease in conversion, in the temperature range of $250-400{ }^{\circ} \mathrm{C}$ can still be observed [64-66]. Despite numerous publications related to the investigation of the poisoning mechanism, only a few solutions have been suggested. One 
of the most promising solutions is the combination of the zeolite SCR catalyst with a mixed oxide that is highly active for hydrocarbon and $\mathrm{NO}$ oxidation, e.g., doped $\mathrm{MnO}_{\mathrm{x}}$ or $\mathrm{CeO}_{2}$ (Figure 10) $[56,70,71]$. Recently, it was suggested that in such composite catalytic systems, an intermediate, presumably nitrate, migrates from the mixed oxide component towards the zeolite $[70,72]$.
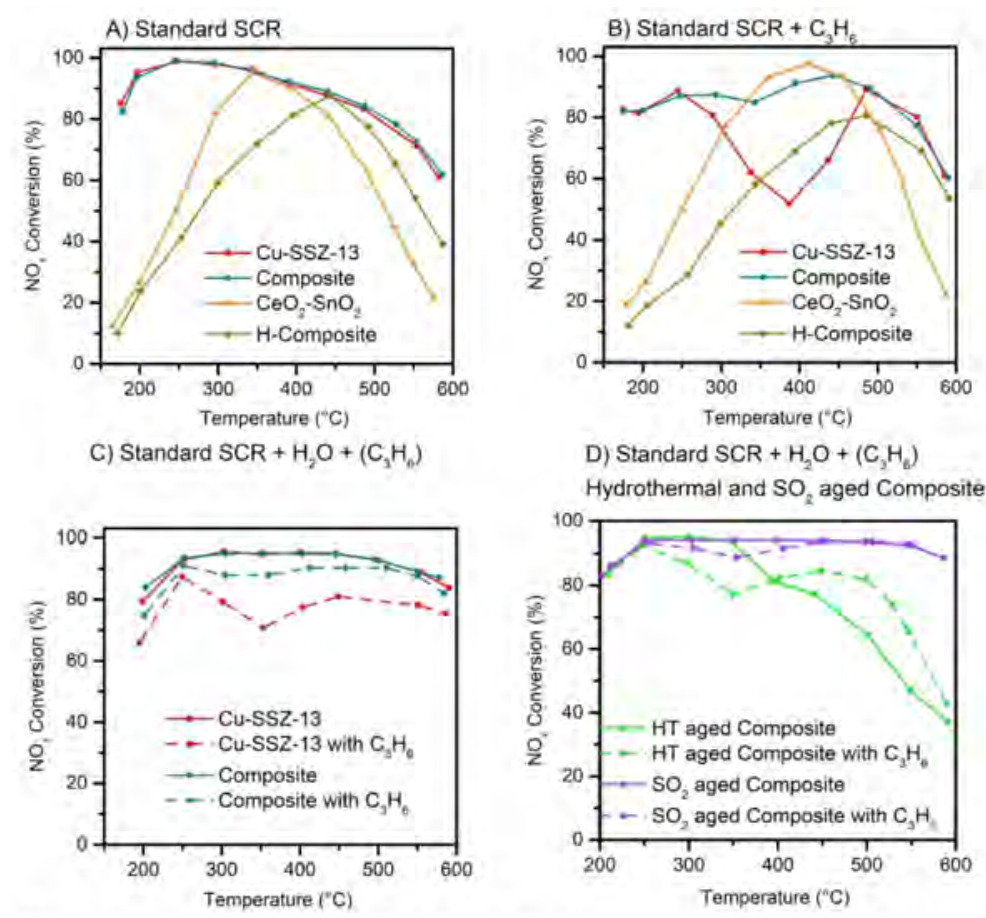

Figure 10. Comparison of the $\mathrm{NO}_{\mathrm{x}} \mathrm{SCR}$ activity of the investigated catalysts: Standard SCR (A), Standard SCR with $\mathrm{HC}(\mathbf{B})$, Standard SCR with $\mathrm{H}_{2} \mathrm{O}$ and $\mathrm{C}_{3} \mathrm{H}_{6}$ added (C), and after ageing and $\mathrm{SO}_{2}$ poisoning (D). Reprinted with permission from ref. [70]. Copyright 2021 Elsevier.

The increased application of diesel engines in low-load conditions, such as urban driving, means that exhaust gas temperatures remain low for greater periods of time. Significant issues are encountered when the temperature is under $200^{\circ} \mathrm{C}$, most notably:

1. The urea thermal decomposition and $\mathrm{NH}_{3}$ generation is kinetically limited under $200{ }^{\circ} \mathrm{C}$. The urea and resulting isocyanide decomposition can be enhanced by using catalysts such as $\mathrm{TiO}_{2}$ and $\mathrm{ZrO}_{2}$. The decomposition towards $\mathrm{NH}_{3}$ can be obtained with $\mathrm{ZrO}_{2}$ already at $150{ }^{\circ} \mathrm{C}$ (Figure 11) [73-75]. Another suggested solution is the use of alternative $\mathrm{NH}^{3}$ carrier substances such as solid salts with low melting and decomposition temperatures [76].

2. The $\mathrm{N}_{2} \mathrm{O}$ production over $\mathrm{Cu}$ zeolites is relatively high and significantly influenced by the zeolite type with the lowest $\mathrm{N}_{2} \mathrm{O}$ production over CHA-type zeolites. This has been explained by the higher stability of $\mathrm{NH}_{4} \mathrm{NO}_{3}$ over the SSZ-13 zeolite relative to ZSM-5 and BEA zeolites due to size-exclusion effects. Another proposal is the use of Fe-zeolites or $\mathrm{V}_{2} \mathrm{O}_{5}-\mathrm{WO}_{3} / \mathrm{TiO}_{2}$ that produce lower amounts of $\mathrm{N}_{2} \mathrm{O}$ per converted NO. These catalysts have poor low temperature performance, but they can be used combined with $\mathrm{Cu}$ zeolites in zoned designs, whereby the $\mathrm{Cu}$ zeolites are located downstream [42,77-80]. 

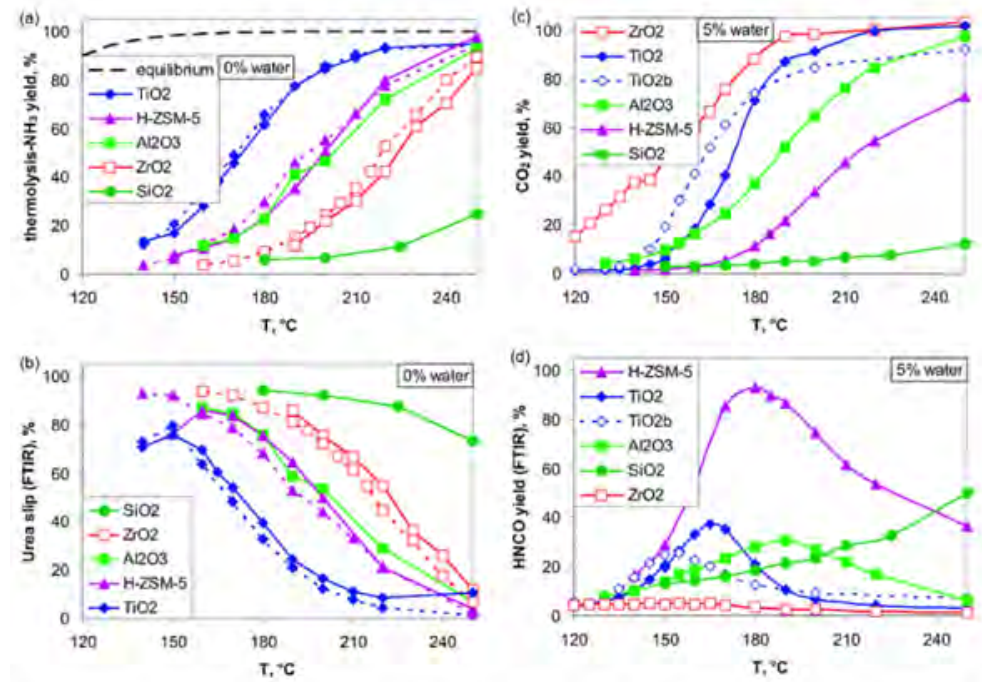

Figure 11. Screening of catalysts for urea decomposition. (a,b) Dry experiments: solid lines—ethanol; dashed lines-methanol. (c,d) Hydrolysis with 5\% water. (a) Includes the $\mathrm{NH}_{3}$ yield according to the thermodynamic equilibrium of the urea thermolysis reaction. Reprinted with permission from ref. [73]. Copyright 2012 Royal Society of Chemistry.

The formation of $\mathrm{N}_{2} \mathrm{O}$ at low temperatures $\left(<300{ }^{\circ} \mathrm{C}\right)$ is hypothesized to occur through the reaction of the adsorbed nitrates with $\mathrm{NH}_{3}$ to form $\mathrm{NH}_{4} \mathrm{NO}_{3}$, which, in turn, decomposes to $\mathrm{N}_{2} \mathrm{O}$ upon heating. Indeed, the frequently reported $\mathrm{N}_{2} \mathrm{O}$ values in literature usually refer to steady-state $\mathrm{N}_{2} \mathrm{O}$ production and do not report the high $\mathrm{N}_{2} \mathrm{O}$ release during the heating phase. $\mathrm{NH}_{4} \mathrm{NO}_{3}$ can form either on the catalyst or spontaneously in the gas phase under $200{ }^{\circ} \mathrm{C}$, and it is typically discussed in a negative context in the scientific literature [29,77,78,81-85]. A recent innovative report, however, discussed $\mathrm{NH}_{4} \mathrm{NO}_{3}$ as a promoter of the SCR reaction, with $\mathrm{NH}_{4} \mathrm{NO}_{3}$ acting as a buffer by supplying nitrates for the Fast SCR reaction when $\mathrm{NO}_{2} / \mathrm{NO}_{\mathrm{x}}<0.5$ and by capturing $\mathrm{NO}_{2}$ when $\mathrm{NO}_{2} / \mathrm{NO}_{\mathrm{x}}$ is higher (Figure 12) [86].

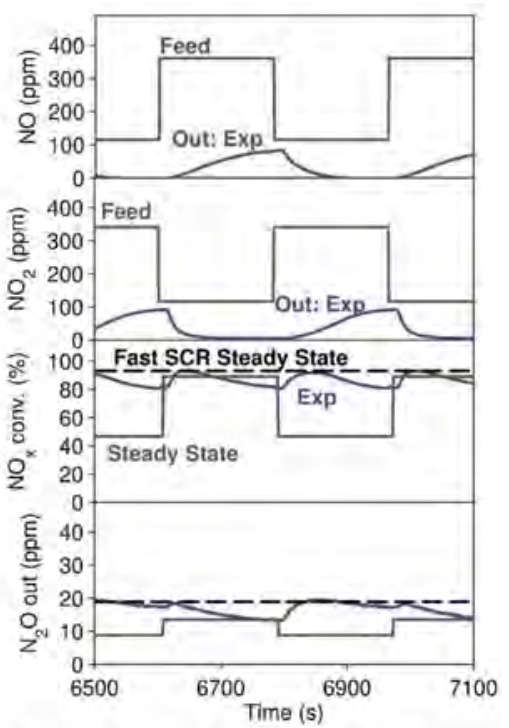

Figure 12. Three-minute step changes between $\mathrm{NO}_{2} / \mathrm{NO}_{\mathrm{x}}=25$ and $75 \%$. Feed $=500 \mathrm{ppm}$ of $\mathrm{NH}_{3}, 500 \mathrm{ppm}$ of $\mathrm{NO}_{\mathrm{x}}, 5 \% \mathrm{H}_{2} \mathrm{O}, 6 \% \mathrm{O}_{2}$, and $\mathrm{N}_{2}$ as balance gas. GHSV at STP $=50,000 \mathrm{~h}^{-1}$. Temperature $=200^{\circ} \mathrm{C}$. Many step changes were completed beforehand, until the catalyst reached the constant, fluctuating behavior shown here. Reprinted with permission from ref. [86]. Copyright 2020 Elsevier. 
It would be reasonable to assume significant interaction of $\mathrm{NH}_{4} \mathrm{NO}_{3}$ and soot over SCRoF when considering the highly oxidative nature of ammonium nitrate and $\mathrm{NO}_{2}$ that forms upon $\mathrm{NH}_{4} \mathrm{NO}_{3}$ decomposition. The $\mathrm{NH}_{4} \mathrm{NO}_{3}$-soot interaction over SCRoF was investigated by Mihai et al. in $[87,88]$, who found a significant enhancement of soot oxidation and hypothesized that extra-framework $\mathrm{Cu}$ was involved in the soot oxidation (Figure 13). No other report dealing with the $\mathrm{NH}_{4} \mathrm{NO}_{3}$-soot interaction over the SCRoF was found, and numerous uncertainties that open avenues for future research remain.

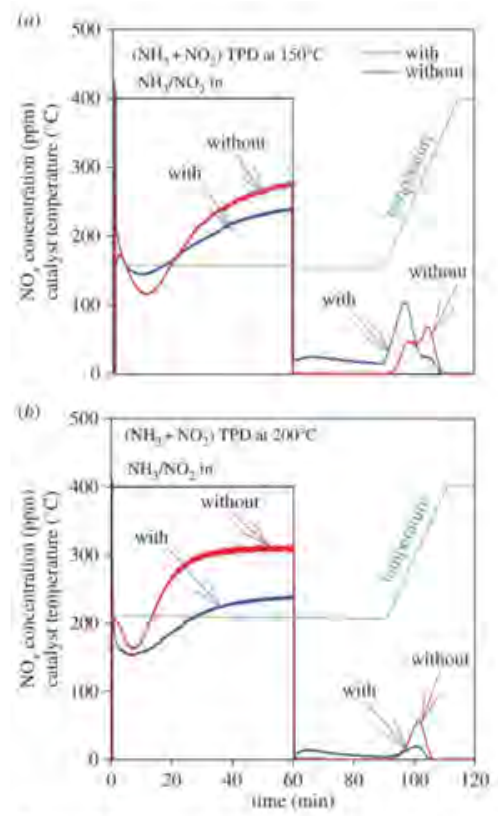

Figure 13. $\mathrm{NO}_{x}$ adsorption and desorption during $\left(\mathrm{NH}_{3}\right.$ and $\left.\mathrm{NO}_{2}\right)$ TPD 'with/without' soot at (a) 150 and (b) $200{ }^{\circ} \mathrm{C}$ conducted over a DPF coated with SCR zeolite catalyst. Adsorption feed:

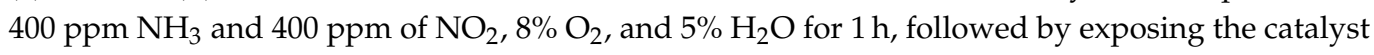
to $5 \% \mathrm{H}_{2} \mathrm{O}$ in Ar for $30 \mathrm{~min}$; thereafter, the temperature was increased to $400{ }^{\circ} \mathrm{C}$. Reprinted with permission from ref. [87]. Copyright 2016 Royal Society of Chemistry.

The CHA structure of the Cu-SSZ-13 can stabilize the ion-exchanged copper and offers a higher hydrothermal resistance than ZSM-5 or BEA. Nevertheless, after repeated active soot regeneration, hydrothermal ageing, and ash deposition, the overall $\mathrm{NO}_{\mathrm{x}}$ activity decreases, and there is interest to increase the lifetime of the SCRoF above 200,000 km. The ageing decreases $\mathrm{NO}_{x}$ conversion, especially at low temperatures, and induces the agglomeration of $\mathrm{Cu}$ to form $\mathrm{CuAl}_{2} \mathrm{O}_{4}$ spinels and $\mathrm{CuO}$ over the zeolite surface. The latter has the effect that the parasitic $\mathrm{NH}_{3}$ oxidation becomes more pronounced, thus giving rise to an increase of $\mathrm{N}_{2} \mathrm{O}$ production and a waste of the reductant; meanwhile, the $\mathrm{NO}_{x}$ conversion at high temperatures decreases. The agglomeration can be reduced to some extent by optimizing the $\mathrm{Cu}$ loading $(2-2.5 \mathrm{wt} \%)$, and a novel solution was recently suggested by Peng et al. [89], whereby Cu-SSZ-13 was impregnated with $\mathrm{ZrO}_{2}$. Upon hydrothermal ageing, the exsolved $\mathrm{CuO}$ was captured and stabilized in the $\mathrm{ZrO}_{2}$ matrix, thereby avoiding $\mathrm{NH}_{3}$ over-oxidation. Other works have shown that co-doping with low amounts of other ions, notably La, Ce [90,91], and K [92], can extend the catalyst lifetime by reducing the structural damage of the zeolite.

The $\mathrm{Cu}-\mathrm{SSZ}-13$ commonly used in SCRoF applications is sensitive to the $\mathrm{SO}_{2}$ present in the gas phase due to the high dispersion of $\mathrm{Cu}$. The $\mathrm{SO}_{2}$ adsorption depends on the location of the $\mathrm{Cu}$ in the zeolite cage and can result in $\mathrm{SSZ}-13-\mathrm{Cu}-\mathrm{SO}_{4}$; if $\mathrm{NH}_{3}$ is also present in the gas phase, $\left(\mathrm{NH}_{4}\right)_{2} \mathrm{SO}_{4}$ deposits that physically blocks the zeolite pores are also formed. The active sites are blocked by the strongly adsorbed $\mathrm{SO}_{2}$ that is thermodynamically stable and requires temperatures well above $500{ }^{\circ} \mathrm{C}$ to decompose. Detailed descriptions of the $\mathrm{SO}_{2}$ deactivation mechanism and its reversibility can be found in numerous manuscripts. The 
management of $\mathrm{SO}_{2}$ poisoning has been limited to two main solutions: thermal desulfation and mixing the $\mathrm{Cu}-\mathrm{SSZ}-13$ with a mixed oxide with a high $\mathrm{SO}_{2}$ adsorption capacity that can delay the deactivation. Despite detailed deactivation studies, innovation in the area of improving the $\mathrm{SO}_{2}$ regeneration is lacking. Over the SCRoF, desulfation can partially take place concurrently with active soot regeneration, and the presence of hydrocarbons can enhance the release of $\mathrm{SO}_{2}$ [93-97].

\section{Combined Technologies Based on LNT Catalysts}

The major challenge in diesel exhaust cleanup is the simultaneous removal of $\mathrm{NO}_{\mathrm{x}}$ under lean (oxygen-rich) conditions to soot. A potential strategy is to combine the CDPF and SCR functions in a selective catalytic reduction and particulate filter, as presented in the previous section. As mentioned before, in addition to SCR, $\mathrm{NO}_{\mathrm{x}}$ reduction from lean burn exhaust gas can be achieved using the cycled LNT system (also called $\mathrm{NO}_{\mathrm{x}}-\mathrm{Storage}$ Reduction or NSR system). Yoshida et al. [98] were the first to propose the use of LNT catalysts for the simultaneous removal of PM and $\mathrm{NO}_{\mathrm{x}}$. This technology, called the DPNR (Diesel Particulate $\mathrm{NO}_{\mathrm{x}}$ Reduction) system, was successfully introduced in 2003 for diesel engines in the Japanese and European markets, and it was further developed under the Toyota D-CAT (Diesel Clean Advanced Technology) concept [99]. In particular, in Europe, the DPNR system was applied to passenger vehicles (Toyota Avensis) that achieved an exhaust emission level much lower than that specified in the Euro 4 regulation. However, the application of DPNR as a "stand-alone" $\mathrm{PM}-\mathrm{NO}_{\mathrm{x}}$ reduction technology has been mostly limited to light-duty applications, i.e., to smaller-sized engines, below about $2 \mathrm{~L}$, due to the fuel economy penalty induced by its regeneration and the large amount of noble metal in its formulations. Moreover, its use as a "stand-alone" technology prevents it from reaching the actual stringent regulations on vehicle emissions

Along these lines, LNT and SCR combined systems have been proposed to enhance $\mathrm{NO}_{x}$ removal efficiency, LNT and DPF combined systems have been proposed to reduce $\mathrm{NO}_{\mathrm{x}}$ and soot, and other more complex combination and integration have been proposed as after-treatment devices.

\subsection{Combined LNT-SCR Systems for $\mathrm{NO}_{x}$ Removal}

The LNT catalyst operates in fast lean/rich transients. During the lean steps of approximately one minute, the gas phase is constituted by the standard exhaust gas from the lean burn engine. Under these conditions, $\mathrm{NO}_{\mathrm{x}}$ are trapped as nitrite/nitrate (depending on the temperature) on the basic components of the catalyst. Before the catalyst becomes completely saturated (i.e., all the adsorption sites are occupied by adsorbed $\mathrm{NO}_{\mathrm{x}}$ ), it should be regenerated. This is carried out during short periods in rich media for few seconds in order to reduce the stored $\mathrm{NO}_{x}$ into $\mathrm{N}_{2}$. Indeed, the rich phases are generated by injecting pulses of fuel, which is immediately transformed into $\mathrm{HC}, \mathrm{CO}$, and $\mathrm{H}_{2}$ on a pre-catalyst (usually a diesel oxidation catalyst implemented before the LNT system). These rich pulses induce exothermic reactions that favor nitrite/nitrate desorption and reduction into nitrogen [100-104]. Unfortunately, this theoretical pathway is complicated by some $\mathrm{NO}_{\mathrm{x}}$ slip during the storage and/or reduction phases and by the formation of by-products like $\mathrm{N}_{2} \mathrm{O}$ and $\mathrm{NH}_{3}$ during the regeneration phase. Thus, for these reasons, an LNT system alone cannot achieve the lowest $\mathrm{NO}_{\mathrm{x}}$ tailpipe emissions over the desired emission certification test cycles.

Thus, logically, the addition of an $\mathrm{NH}_{3}-\mathrm{SCR}$ catalyst to the LNT catalyst has been proposed in order to increase global $\mathrm{NO}_{x}$ abatement and $\mathrm{N}_{2}$ selectivity [105-112]. Indeed, $\mathrm{NH}_{3}$ produced by the LNT system is firstly stored on the downstream SCR catalytic bed. During the next lean period, this stored $\mathrm{NH}_{3}$ can react with $\mathrm{NO}_{\mathrm{x}}$ passing through the $\mathrm{NO}_{\mathrm{x}^{-}}$ trap via the $\mathrm{NH}_{3}-\mathrm{SCR}$ reaction [100]. In this way, the $\mathrm{NH}_{3}$ emissions due to the LNT system is avoided and the necessity of an on-board urea tank for the $\mathrm{NH}_{3}$ supply is eliminated [105]. The key point is to generate enough $\mathrm{NH}_{3}$ on the LNT catalyst for the SCR system. Such a combined system is commonly named LNT-SCR or better LNT-passive SCR. 
Recently, many studies on different possible LNT-SCR configurations have been published [6]. The first combined LNT-SCR system, with an upstream LNT and a downstream SCR, was patented by Ford Motor Co. in 2002 [113]; in 2007, the system became commercially implemented in the Mercedes E320 Blue-Tech vehicle [114]. In addition to the LNT-passive SCR system, other combination systems, like passive $\mathrm{NO}_{\mathrm{x}}$ adsorber (PNA) and active SCR or LNT and active SCR, have been proposed; in both cases, SCR operates with urea dosing.

\subsubsection{Fundamental Studies on LNT-Passive SCR Combined System}

A fundamental investigation of the sequential LNT/SCR system and the LNT and SCR physical mixture was reported by Castoldi et al. [109,113]. A traditional homemade LNT catalyst (i.e., Pt-Ba/ $\mathrm{Al}_{2} \mathrm{O}_{3}$ ) was considered, while an Fe-doped zeolite (i.e., Fe/ZSM-5) represented the SCR system; both dual bed and mechanical mixture configurations were considered. Through FT-IR spectrospic analysis, the authors demonstrated that the $\mathrm{NH}_{3}$ formed over the LNT catalyst was an intermediate in the NO stored reduction and that it was subsequently adsorbed over the downstream SCR catalyst. Moreover, the reported results demonstrated that the stand-alone $\mathrm{Pt}-\mathrm{Ba} / \mathrm{Al}_{2} \mathrm{O}_{3}$ catalyst was able to store $\mathrm{NO}_{\mathrm{x}}$ and to oxidize $\mathrm{NO}$ to $\mathrm{NO}_{2}$ under lean conditions (Figure 14A), initially forming nitrites (band at $1220 \mathrm{~cm}-1$ ) that were progressively transformed into nitrates (bands at 1545, 1416, 1328, and $1035 \mathrm{~cm}^{-1}$ ), so that only nitrates were present at the end of the storage (bands 1416, 1328 , and $1035 \mathrm{~cm}^{-1}$ ) (Figure 14C). During the rich phase, most of the formed nitrates were readily consumed to give $\mathrm{N}_{2}$ at first and $\mathrm{NH}_{3}$ later on (Figure 14B,D).
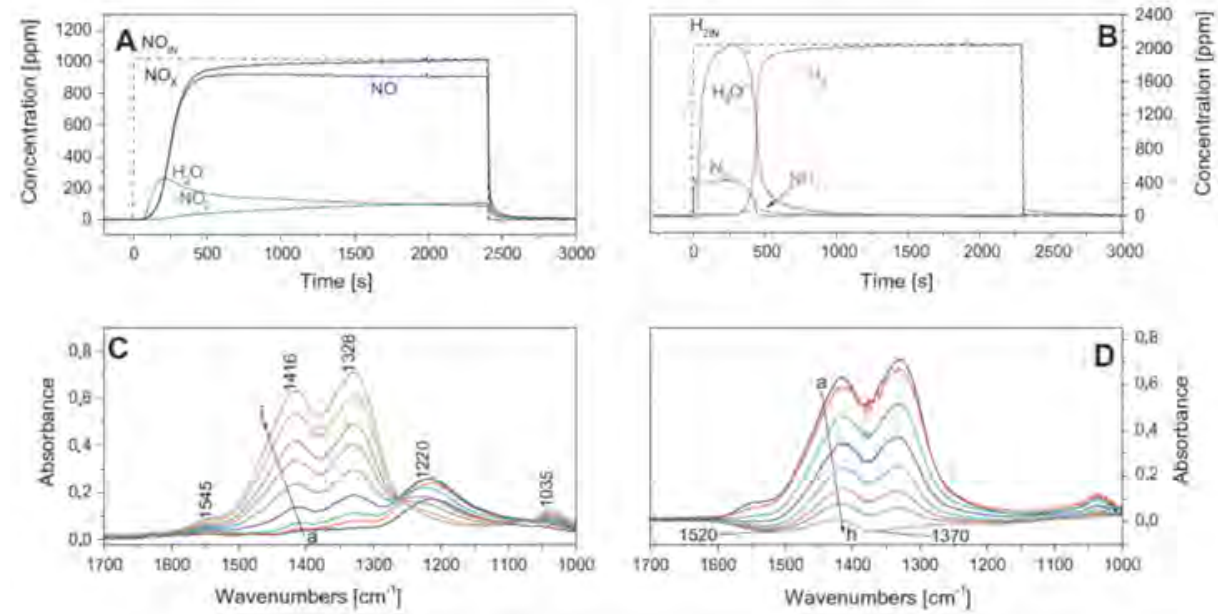

Figure 14. Lean-rich cycle carried out at $250{ }^{\circ} \mathrm{C}$ over LNT Pt-Ba $/ \mathrm{Al}_{2} \mathrm{O}_{3}$ catalyst. (A) ISC experiment, lean phase: $1000 \mathrm{ppm}$ of $\mathrm{NO}$ in $\mathrm{He}$ and $\mathrm{O}_{2}(3 \% \mathrm{v} / v)$. (B) ISC experiment, rich phase: $2000 \mathrm{ppm}$ of $\mathrm{H}_{2}$ in $\mathrm{He}$, catalyst loading of $60 \mathrm{mg}$, and total flow rate of $100 \mathrm{~cm}^{3} / \mathrm{min}$ (at $1 \mathrm{~atm}$ and $0{ }^{\circ} \mathrm{C}$ ). (C) FTIR spectra recorded upon the admission of $\mathrm{NO} / \mathrm{O}_{2}(1: 4)$ mixture at $250{ }^{\circ} \mathrm{C}$ for $30 \mathrm{~s}$ (curve a), $1 \mathrm{~min}$ (curve b), 2 min (curve c), $5 \mathrm{~min}$ (curve d), $10 \mathrm{~min}$ (curve e), $15 \mathrm{~min}$ (curve f), $20 \mathrm{~min}$ (curve g), $30 \mathrm{~min}$ (curve h), and $40 \mathrm{~min}$ (curve i). (D) FTIR spectra recorded during $\mathrm{NO}_{\mathrm{x}}$ reduction at $250{ }^{\circ} \mathrm{C}$ at increasing contact times-curve a is the spectrum of the $\mathrm{NO}_{\mathrm{x}}$ stored by $\mathrm{NO} / \mathrm{O}_{2}$ at $250{ }^{\circ} \mathrm{C}$, evacuated at $250{ }^{\circ} \mathrm{C}$; curves $\mathrm{b}-\mathrm{h}$ are spectra recorded upon $\mathrm{H}_{2}$ (5 mbar) interaction for $15 \mathrm{~s}$ (curve b), $30 \mathrm{~s}$ (curve c), 1 min (curve d), 2 min (curve e), 5 min (curve f), 15 min (curve g), and 30 min (curve h) - catalyst loading of $60 \mathrm{mg}$ and total flow rate of $100 \mathrm{~cm}^{3} / \mathrm{min}$ (at $1 \mathrm{~atm}$ and $0{ }^{\circ} \mathrm{C}$ ). Reprinted with permission from ref. [109]. Copyright 2011 Elsevier.

On the other hand, when using the dual zoned configuration, remarkable amounts of $\mathrm{N}_{2}$ and of $\mathrm{H}_{2} \mathrm{O}$ are formed in the lean phase (Figure 15A). Comparing the results with those obtained in the case of a stand-alone LNT catalyst (Figure 14A), the authors demonstrated that $\mathrm{NH}_{3}$ stored on the SCR layer during the previous rich phase was consumed by the SCR reaction upon the admission of $\mathrm{NO} / \mathrm{O}_{2}$. Notably, $\mathrm{N}_{2}$ evolution was observed with a 
delay but before the $\mathrm{NO}_{\mathrm{x}}$ breakthrough, as expected from the reaction of $\mathrm{NH}_{3}$ stored over the SCR catalyst with $\mathrm{NO}_{x}$ slipped from the upstream LNT catalyst. Then, upon the rich phase, when $\mathrm{H}_{2}$ was fed to the reactor, remarkable amounts of $\mathrm{N}_{2}$ were formed but no $\mathrm{NH}_{3}$ evolution was detected because it was trapped over the SCR catalyst placed downstream. Accordingly, the $\mathrm{NO}_{x}$ removal efficiency was increased and the $\mathrm{NH}_{3}$ slip reduced [109].
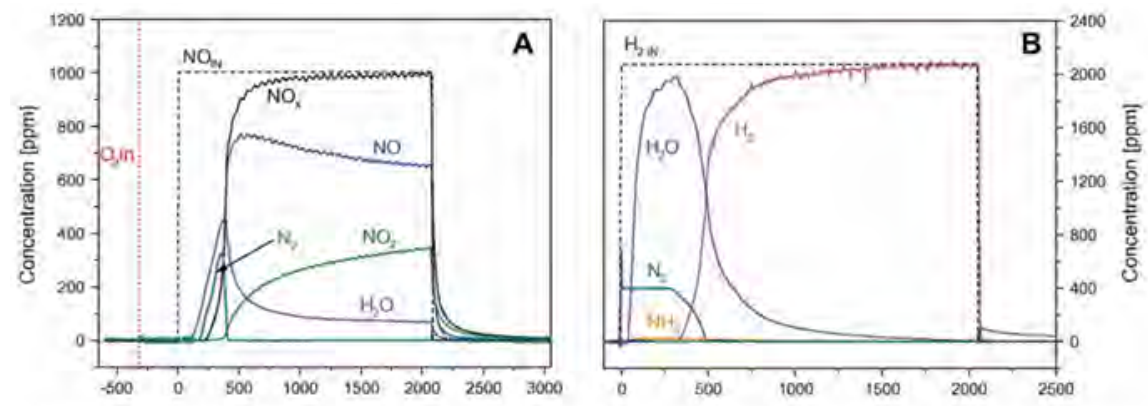

Figure 15. ISC experiments with lean-rich cycles carried out at $250{ }^{\circ} \mathrm{C}$ over an LNT/SCR dual bed. (A) Lean phase: 1000 ppm of $\mathrm{NO}$ in $\mathrm{He}$ and $\mathrm{O}_{2}(3 \% v / v)$. (B) Rich phase: 2000 ppm of $\mathrm{H}_{2}$ in He, catalyst loading of $60 \mathrm{mg}$ LNT and $60 \mathrm{mg}$ of SCR, and total flow rate of $100 \mathrm{~cm}^{3} / \mathrm{min}$ (at $1 \mathrm{~atm}$ and $\left.0{ }^{\circ} \mathrm{C}\right)$. Reprinted with permission from ref. [109]. Copyright 2011 Elsevier.

Those results have been confirmed by other authors using different catalysts for LNT (i.e., $\mathrm{Pt}-\mathrm{Rh}-\mathrm{Ba} / \mathrm{Al}_{2} \mathrm{O}_{3}$, [115,116]) or SCR (i.e., $\mathrm{Cu}-\mathrm{ZSM}-5$ was partially substituted with $\mathrm{Co} / \mathrm{Al}_{2} \mathrm{O}_{3}$, [117]). The results reported by De La Torre et al. [118] showed that $\mathrm{Cu}$-based catalysts are preferable to Fe-zeolites. This is due to the higher reactivity of $\mathrm{Cu}$-based zeolites, in particular $\mathrm{Cu}$-chabazite, at low temperatures where $\mathrm{NH}_{3}$ is preferably formed over upstream NSR catalysts $[119,120]$.

Gonzalez-Velasco and coworkers pointed out that the performances of coupled LNTSCR systems could be optimized by operating under conditions favoring $\mathrm{NH}_{3}$ formation to be adsorbed over the SCR catalyst [107]. Other authors from the same research group investigated convenient operating conditions for increasing $\mathrm{NO}_{x}$ removal and decreasing $\mathrm{NH}_{3}$ production at the reactor outlet; by developing a complete 3D map, they found that the combined LNT-SCR system achieved the best operation conditions at $200{ }^{\circ} \mathrm{C}$ in excess of $\mathrm{H}_{2}$ (higher than 3\%), with $\mathrm{N}_{2}$ selectivity near 93\% [121].

It has been demonstrated that $\mathrm{NH}_{3}$ is the connection between LNT and SCR, however a non- $\mathrm{NH}_{3}$ pathway for $\mathrm{NO}_{x}$ reduction cannot be excluded, such as other hydrocarbons. For this reason, it is important to investigate how different reducing agents influence the production of $\mathrm{NH}_{3}$ and the by-product formation at the outlet of the LNT catalytic bed. Recently, this aspect was investigated by Urrutxua et al. [122] by combining $\mathrm{Pt}-\mathrm{Ba}(-\mathrm{Ce}) / \mathrm{Al}_{2} \mathrm{O}_{3}$ as the LNT catalyst with the $\mathrm{Cu} / \mathrm{BETA}$ and $\mathrm{Cu} / \mathrm{SAPO}-34$ monoliths as the SCR catalyst. The results showed that $\mathrm{H}_{2}$ and $\mathrm{CO}$ are equally efficient in $\mathrm{NO}_{x}$ reduction starting from $300{ }^{\circ} \mathrm{C}$ (at lower temperatures, only $\mathrm{H}_{2}$ is active), while propylene becomes effective at temperatures near $400{ }^{\circ} \mathrm{C}$. However, since $\mathrm{NH}_{3}$ is mainly produced when $\mathrm{H}_{2}$ is used as a reductant (also at low temperatures), the beneficial effects of the LNT-SCR combined configuration are very evident in these conditions but less appreciated at higher temperatures with $\mathrm{CO}$ and/or propylene.

In order to improve $\mathrm{NO}$ to $\mathrm{NO}_{2}$ oxidation (a key step in the storage phase of LNT catalysts) and to reduce the cost of PGM-based catalysts, La-based perovskites have been studied as alternatives to Pt-based LNT catalysts. In this context, González-Velasco and co-worker [105] studied the DeNO $\mathrm{x}_{\mathrm{x}}$ activity of a novel $0.5 \% \mathrm{Pd}-30 \% \mathrm{La}_{0.5} \mathrm{Ba}_{0.5} \mathrm{CoO}_{3} / \mathrm{Al}_{2} \mathrm{O}_{3}$ perovskite formulation in its application to the combined LNT-SCR systems, where a $4 \% \mathrm{Cu} / \mathrm{SAPO}-34 \mathrm{SCR}$ catalyst was placed downstream of the perovskite-based catalyst. The obtained results are reported in Figure 16as response surface and corresponding 2D isocurves of $\mathrm{NO}_{x}$ removal and $\mathrm{NH}_{3}$ and $\mathrm{N}_{2}$ production, respectively, for the sequential LNT-SCR configuration in the LNT and SCR temperature domains. On the basis of 
the reported results in Figure 16, the authors demonstrated that the optimal operating temperature for the novel LNT-SCR system was $300^{\circ} \mathrm{C}$ in both catalytic beds, and the best hydrogen concentration was $3 \%$. In these conditions, the maximum $\mathrm{N}_{2}$ production was near $92 \%$, while $\mathrm{NH}_{3}$ slip and $\mathrm{N}_{2} \mathrm{O}$ production were nearly zero.

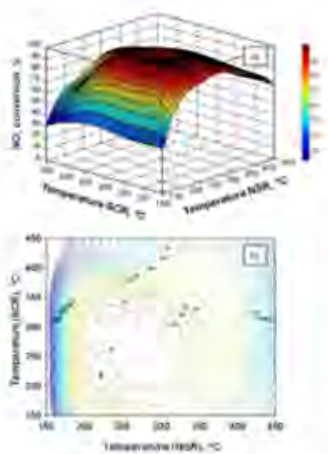

(A)

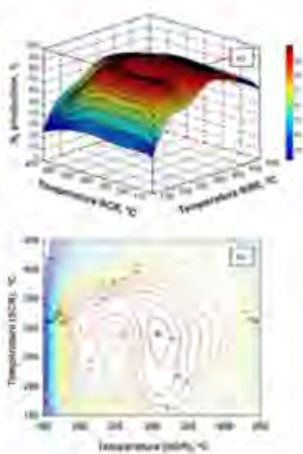

(B)

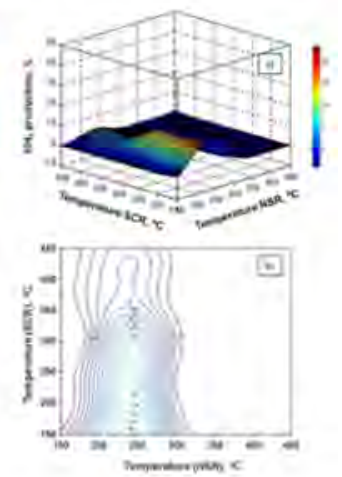

(C)

Figure 16. (A) (a) Response surface for $\mathrm{NO}_{\mathrm{x}}$ conversion in the NSR and SCR catalyst temperature domains for the NSR-SCR configuration. (b) Isocurves corresponding to different levels of $\mathrm{NO}_{\mathrm{x}}$ conversion projected to the $\mathrm{T}_{\mathrm{NSR}}-\mathrm{T}_{\mathrm{SCR}}$ space. (B) (a) Response surface for $\mathrm{N}_{2}$ production in the NSR and SCR catalyst temperature domains for the NSR-SCR configuration. (b) Isocurves corresponding to different levels of $\mathrm{N}_{2}$ production projected to the $\mathrm{T}_{\mathrm{NSR}}-\mathrm{T}_{\mathrm{SCR}}$ space. (C) (a) Response surface for $\mathrm{NH}_{3}$ production in the NSR and SCR catalyst temperature domains for the NSR-SCR configuration. (b) Isocurves corresponding to different levels of $\mathrm{NH}_{3}$ production projected to the $\mathrm{T}_{\mathrm{NSR}}-\mathrm{T}_{\mathrm{SCR}}$ space. Adapted with permission from ref. [105] Copyright 2021 American Chemical Society.

\subsubsection{Performances of Combined LNT-Passive SCR Systems}

Ford Motor Company [67,106] performed an in-depth investigation of the behavior of the so-called second-generation LNT and SCR systems developed by Ford's catalyst suppliers in 2007-2008. The combined system was tested with vehicle tests, and its benefit in the $\mathrm{NO}_{\mathrm{x}}$ reduction efficiency compared to the LNT alone was immediately evident, with an increase of the $\mathrm{NO}_{x}$ conversion from a range of 78-93\% for the LNT alone to 93-97\% when including the SCR layer. The observed enhancement in the $\mathrm{NO}_{\mathbf{x}}$ conversion was explained by considering the presence of hydrocarbons (like propylene) that slipped through the LNT catalyst and reacted with $\mathrm{NO}_{x}$ over the SCR catalyst [67].

The combined LNT-SCR system seems to also overcome drawbacks due to hydrothermal aging and sulfur poisoning. Indeed, C. Seo et al. [123] demonstrated that, although the $\mathrm{NO}_{\mathrm{x}}$ storage can be decreased due to hydrothermal aging $\left(750-900{ }^{\circ} \mathrm{C}\right)$ and sulfur poisoning, overall $\mathrm{NO}_{x}$ conversion over the LNT and SCR catalyst is still 10-30\% higher than that over the single LNT system because more $\mathrm{NH}_{3}$ slips due to aging and sulfuring poisoning can be stored onto the downstream SCR and followed by the $\mathrm{NH}_{3}-\mathrm{SCR}$ reactions to give nitrogen. Additionally, $\mathrm{N}_{2} \mathrm{O}$ emissions are lower because most of the stored $\mathrm{NO}_{x}$ is fully reduced.

To achieve a global optimization of the LNT and SCR system, LNT and SCR structures such as zoning versus layering should also be considered [124,125]. Indeed, two configurations have been proposed, i.e., dual-layer and dual-brick. In the dual-layer system, the $\mathrm{NH}_{3}$ formed at the underlying NSR layer is stored onto the top layer of the SCR catalyst. During the sequent lean phase, NO in the gas phase firstly reached the top SCR layer and reacted with stored $\mathrm{NH}_{3}$, before reaching the underlying layer of NSR by mass diffusion (Figure 17). As expected, an optimization of the catalyst loadings was necessary in this configuration; as reported by Shakya et al. [124], for higher SCR washcoat loading, the amount of $\mathrm{NH}_{3}$ generated in the NSR catalyst was not sufficient to fully utilize the adsorption sites in the SCR. As a result, only a fraction of the SCR closer to the NSR layer was utilized, while the 
rest acted as an inert layer that created an undesired diffusional barrier that lowered the $\mathrm{NO}_{\mathrm{x}}$ conversion.

(a)
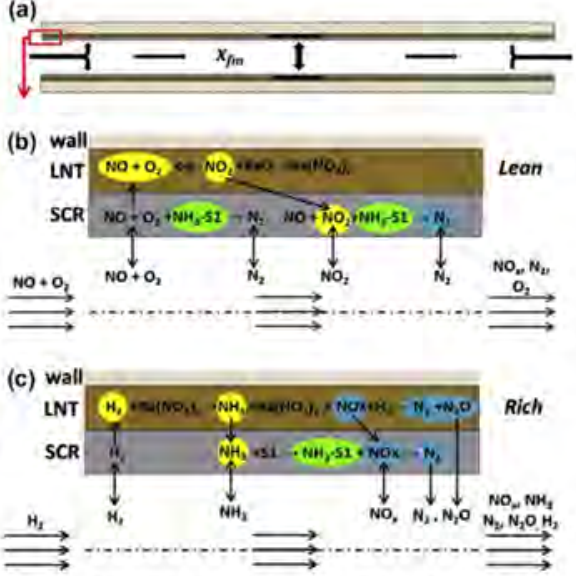

Figure 17. (a) Schematic of a monolithic channel coated with two layers of washcoat (SCR layer on top of LNT; SCR layer exposed to the fluid phase), (b) expanded portion of the washcoated channel showing the key reactions occurring within the washcoat during the lean phase, and (c) the rich phase after the first cycle. (Note: in the first cycle, no $\mathrm{NH}_{3}-\mathrm{S} 1$ is present in the SCR layer). Reprinted with permission from ref. [124]. Copyright 2013 Elsevier.

The dual layer configuration was also investigated by Honda R\&D Co., Ltd, Japan [126-128], confirming the already explained chemistry. As clearly shown in Figure 18, which shows the reduction phase over the single $\mathrm{LNT} 1$ catalyst (i.e., $\mathrm{Pt}-\mathrm{Rh}-\mathrm{BaO} / \mathrm{Al}_{2} \mathrm{O}_{3}$ ), the production of $\mathrm{N}_{2}$ and $\mathrm{NH}_{3}$ was observed as result of stored $\mathrm{NO}_{x}$ reduction; their concentration decreased in the subsequent lean phase, where $\mathrm{NO}_{\mathrm{x}}$ adsorption occurred. On the other hand, in the dual layer configuration where the Cu-ZSM-5 SCR monolith represents the top layer and LNT1 represents the bottom layer (CuZ and LNT1 in Figure 18), only $\mathrm{N}_{2}$ was observed while $\mathrm{NH}_{3}$ was stored on SCR layer during the rich phase; a new $\mathrm{N}_{2}$ evolution was observed in the lean phase when $\mathrm{NH}_{3}$ previously adsorbed on $\mathrm{CuZ}$ was used to reduce $\mathrm{NO}_{\mathrm{x}}$.

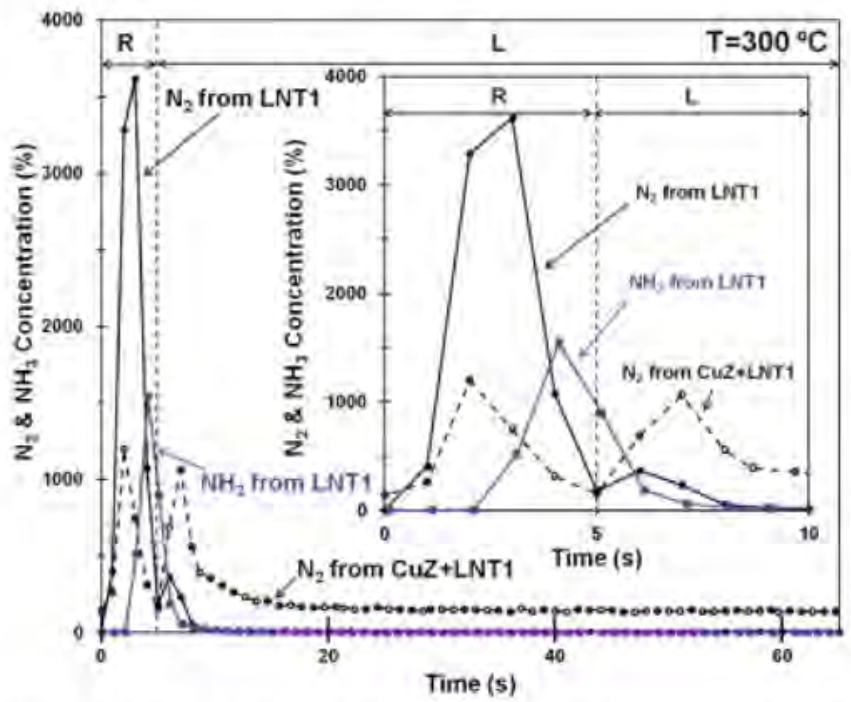

Figure 18. Comparison of $\mathrm{N}_{2}$ and $\mathrm{NH}_{3}$ outlet concentrations from LNT1 and dual layer CuZ-LNT1 catalysts. The inlet composition of the rich phase is as follows: (R): $2.5 \% \mathrm{H}_{2}$ and Ar in balance; the inlet composition of the lean phase is as follows: (L): $500 \mathrm{ppm}$ of $\mathrm{NO}, 5 \% \mathrm{O}_{2}$, and Ar in balance. Reprinted with permission from ref. [129]. Copyright 2012 Elsevier. 
Other combined configurations have also been studied; e.g., two LNT-SCR monoliths in series $[107,110,130]$, where $\mathrm{Pt} / \mathrm{Ba} / \mathrm{Al}_{2} \mathrm{O}_{3}$ represents the LNT catalyst and Fe-beta zeolite is the SCR catalyst; this system provides an extremely high $\mathrm{NO}_{\mathrm{x}}$ removal efficiency, near $99.5 \%$ at $300{ }^{\circ} \mathrm{C}$. Additionally, Shakya et al. [124] investigated the dual brick configuration in the same experimental conditions of the dual layer system, and they found that the former was much less performing than the latter, mostly because the $\mathrm{NH}_{3}$ generated in the LNT layer was better utilized in the SCR layer. However, at higher temperatures, the functionality of the SCR component was greatly reduced because of the higher rate of $\mathrm{NH}_{3}$ consumption in the NSR layer that lowered the amount of $\mathrm{NH}_{3}$ reaching the SCR catalyst: under these conditions, comparable performances were obtained for both catalyst configurations.

Additionally, Zheng et al. [131] compared the DeNO $\mathrm{D}_{\mathbf{x}}$ performances obtained over different system configurations (dual-layer vs. dual bed) under fast-cycling conditions. Figure 19 illustrates that the best low-temperature $\mathrm{DeNO}_{\mathbf{x}}$ performances were achieved with the dual-layer catalyst configuration, suggesting that the close proximity of the LNT and SCR catalysts is needed to fully exploit the SCR NO reduction mechanism. However, the high-temperature $\mathrm{DeNO}_{x}$ performance was negatively impacted by the addition of the SCR top-layer, probably due to diffusional limitations caused by the top-layer that limited the reductant supply to the underlying LNT layer.

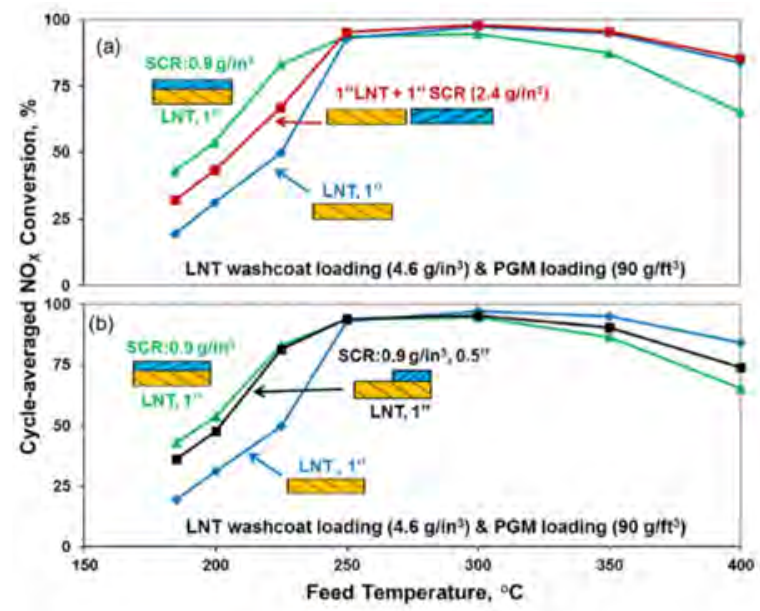

Figure 19. Cycle-averaged $\mathrm{NO}_{x}$ conversions as a function of feed temperature for LNT, dual-layer plus either (a) dual-brick or (b) zoned dual-layer catalysts under fast cycling. Reprinted with permission from ref. [131]. Copyright 2016 Elsevier.

To overcome these problems, a more complex architecture was proposed by Liu and co-worker [132]. The authors proposed a configuration described as "separate zoned and dual layer catalysts", where the $\mathrm{Pt}-\mathrm{Rh}-\mathrm{BaO} / \mathrm{Al}_{2} \mathrm{O}_{3} \mathrm{LNT}$ was located at the front, the $\mathrm{Pt}-\mathrm{Rh}-\mathrm{BaO}-\mathrm{CeO}_{2} / \mathrm{Al}_{2} \mathrm{O}_{3}$ LNT was located at the back of the monolith, and the SCR layer was deposited over the length. Then, in a follow-up study, an increased complexity where the SCR catalyst was also zoned was considered. The mechanism of $\mathrm{NO}_{\mathrm{x}}$ decomposition by zoned-dual layer LNT-SCR catalysts above $200{ }^{\circ} \mathrm{C}$ is well-explained in Figure 20 [125]. The results demonstrate that when using this configuration in the $200-400{ }^{\circ} \mathrm{C}$ temperature range, the $\mathrm{NO}_{x}$ conversion was near $80 \%$ using $2.5 \% \mathrm{H}_{2}$ as the reductant and slightly lower when using a $1 \% \mathrm{CO}$ and $1.5 \% \mathrm{H}_{2}$ mixture. 


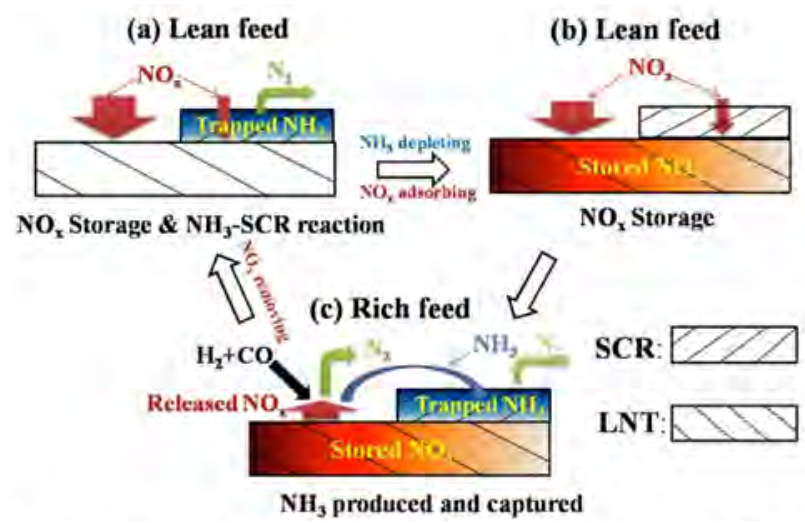

Figure 20. Mechanism of $\mathrm{NO}_{x}$ decomposition by zoned-dual layer LNT-SCR catalysts above $200{ }^{\circ} \mathrm{C}$. Reprinted with permission from ref. [125]. Copyright 2014 Elsevier.

A promising approach to address cold-start $\mathrm{NO}_{x}$ emissions is to employ a passive $\mathrm{NO}_{\mathrm{x}}$ adsorber (PNA) material upstream of the main catalytic converter (SCR); an efficient PNA is designed to adsorb $\mathrm{NO}_{\mathrm{x}}$, preferably $\mathrm{NO}$, during the cold-start period and then readily release them once the SCR system becomes operational. The most promising and investigated PNA formulation with the highest low-temperature NO storage capacity is Pd-exchanged zeolite, most commonly $\mathrm{Pd}-\mathrm{SSZ}-13$ and $\mathrm{Pd} / \mathrm{CeO}_{2}$. PNA should thermally release $\mathrm{NO}_{x}$ under continuous lean conditions at higher temperatures $\left(200-350{ }^{\circ} \mathrm{C}\right)$, where the catalytic converter efficiently functions. The elimination of the need for rich purging significantly enhances fuel economy and engine durability, as well as simplifying electronic control. In this case, the SCR is conventionally operated by active urea dosing control [133-135].

The highest potential $\mathrm{NO}_{\mathrm{x}}$ conversion is given by combinations of two active systems, e.g., LNT including rich regeneration and urea-based SCR. However, the LNT and active SC-based system has shown the maximum packaging, cost, and system complexity issues.

\subsection{Combined LNT-CDPF Systems for Simultaneous NOx and Soot Removal}

The coupling between $\mathrm{NO}_{\mathrm{x}}$ reduction systems and PM removal devices has also been proposed; the most common are CRT ${ }^{\circledR}$ (continuous regeneration trap) DPF systems and diesel particulate $\mathrm{NO}_{\mathrm{x}}$ reduction (DPNR) systems. Unfortunately, the luck of the latter is limited by sulfur poisoning. Indeed, since the formulation is identical to that of the LNT catalyst, DPNR is deactivated by sulfur adsorption and needs regeneration, thus implying a high fuel penalty (fuel consumption and long duration for rich injection).

A CRT system was proposed by Johnson Matthey $[136,137]$. This system exploits the oxidant capacity of an upstream DOC to produce $\mathrm{NO}_{2}$ that, being a stronger oxidant than $\mathrm{O}_{2}$, decreases the soot combustion temperature in the downstream DPF. The main steps are: (i) the oxidation of $\mathrm{NO}$ to $\mathrm{NO}_{2}$ in the DOC, (ii) the oxidation of $\mathrm{PM}$ to $\mathrm{CO}_{2}$ by $\mathrm{NO}_{2}$ with the formation of $\mathrm{NO}$, and (iii) the reoxidation of $\mathrm{NO}$ to $\mathrm{NO}_{2}$. However, such an $\mathrm{NO}_{2}$ slip is the main drawback of this technology [138]. Johnson Matthey further refined the CRT system by directly coating the filter with a catalyst, thus improving the temperature range for the filter regeneration; this new technology is called the catalyzed continuously regenerating trap (CCRT) system.

There are other combined solutions, e.g., where LNT systems are positioned upstream to the CDPF and where LNT is downstream to the CDPF. Schejbal et al. $[139,140]$ studied the arrangement that is presented in Figure 21 and formed by the DOC, CDPF, and NSRC in series. 


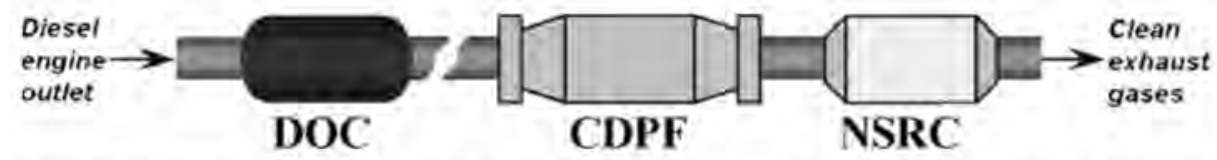

Figure 21. Scheme of the train of monolithic aftertreatment devices. Reprinted with permission from ref. [140]. Copyright 2010 Elsevier.

When the driving cycle starts, the temperatures are so low that they negatively influence the kinetics of the catalytic reactions so that the conversion of $\mathrm{CO}$ and $\mathrm{HC}$ on the DOC is low. As soon as an increase of temperature occurs, the catalytic processes take place and the oxidation of these species becomes effective, at least under the lean conditions. Indeed, when the gas composition becomes rich (i.e., during the regeneration phase of the NSRC catalyst), a large amount of carbon monoxide and/or hydrocarbon cannot be oxidized on the DOC and are directly used as $\mathrm{NO}_{\mathrm{x}}$ reductants in the NSRC monolith.

$\mathrm{NO}_{x}$ goes through the DOC and CDPF to be stored on the NSRC, resulting in an $\mathrm{NO}_{\mathrm{x}}$ delay at the outlet and a significant apparent $\mathrm{NO}_{x}$ conversion. Additionally, in this case, the temperature plays an important role since the $\mathrm{NO}_{x}$ storage capacity is relatively low at low temperatures (lower than $250{ }^{\circ} \mathrm{C}$ ) and gradually increases with temperature (being maximum at $350^{\circ} \mathrm{C}$ ); the same occurs with the regeneration, the efficiency of which is poor at low temperatures.

Above a certain temperature $\left(>200{ }^{\circ} \mathrm{C}\right)$ the DOC efficiently converts part of $\mathrm{NO}$ to $\mathrm{NO}_{2}$, which is created by the soot combustion in the CDPF. Moreover, the presence of $\mathrm{NO}_{2}$ enhances NSRC performance because these species is more efficiently stored.

The main conclusion of these studies is that it is impossible to treat each catalytic converter one-by-one in combined systems. Indeed, the operating conditions may affect the performance of each converter that could co-operate or work competitively with each other. For example, the increased concentration of $\mathrm{NO}_{2}$ in the gas favoring soot oxidation is an example of co-operation between the DOC and DPF. On the other hand, since $\mathrm{NO}_{2}$ is used by both the CDPF and NSRC, a competitive action is observed because both converters consume $\mathrm{NO}_{2}$. Furthermore, studies have generally demonstrated that to obtain satisfactory performance during the cold-start period, the DOC should have a relatively small size, while downsizing of the CDPF is limited by pressure drop and regeneration difficulties. To reach acceptable $\mathrm{NO}_{x}$ adsorption and conversion, the NSRC must have a relatively larger size.

Choi and co-workers [141] proposed a new system for the abatement of NOx and soot, where a homemade $\mathrm{Pt}-\mathrm{Ba} / \mathrm{Al}_{2} \mathrm{O}_{3}$ LNT catalyst, eventually doped with cobalt as an additive to improve $\mathrm{NO}_{x}$ conversion, was coated onto DPF (300 cpsi and 50\% porosity). This resulted in the LNT catalyst permeating into the fine pores in the DPF, thus causing partial clogging; this phenomenon is strictly related to the amount of the LNT catalyst (i.e., lower amounts of catalysts lead to lower back-pressure). Considering both the $\mathrm{NO}_{\mathrm{x}}$ conversion and the pressure drops, $80 \mathrm{~g} / \mathrm{L}$ of LNT is a reasonable amount. In conclusion, the authors revealed that the LNT (2Pt2Ba5Co)/CDPF system improved the $\mathrm{NO}_{\mathrm{x}}$ conversion performance, and it could improve the PM oxidation rate compared to a bare DPF.

However, this configuration also shows issues to be faced in order to smoothly use the LNT/DPF system. For example, sulfur in the engine exhaust plays a major role in gradually eliminating $\mathrm{NO}_{\mathrm{x}}$ storage sites, thus leading to the deactivation of the LNT catalyst. LNT poisoning is caused due to some unwanted reactivity in the form of sulfur compounds that are present in exhaust gases [142]. Indeed, $\mathrm{SO}_{\mathrm{x}}$ reacts with storage material to form sulphates that are more stable than nitrates. Sulfur compounds get gradually saturated on the storage material, which leads to a loss of efficiency for $\mathrm{NO}_{\mathrm{x}}$ storage. To maintain the $\mathrm{DeNO}_{\mathrm{x}}$ efficiency, periodic desulfation by heating at higher temperatures is required, which is detrimental to the life of the catalyst. The temperature of the system is controlled by gas composition, temperature, and the length of the rich pulse. Due to the desulfation period, the fuel penalty for the catalyst operation increases; moreover, due to insufficient catalyst operating temperature, there is a decrease in LNT efficiency [141-144]. In order 
to better understand the role of the LNT component in the sulfur poisoning process, different LNT catalyst formulations were studied by De Abreu Goes et al. [145]. The authors demonstrated that the addition of Pd and Mg into an LNT formulation had a beneficial effect on the desulfation process by decreasing the temperature at which the sulfur trapped was released $\left(\mathrm{T}_{90}<700^{\circ} \mathrm{C}\right)$ and performing efficient sulfur removal with a low $\mathrm{H}_{2}$ consumption.

The more complex system of the LNT/DPF and SCR/DPF was proposed by Kang et al. [146] (Figure 22). This hybrid technology exhibits an $\mathrm{NO}_{x}$ conversion near $40 \%$, as compared to the $25 \%$ of the simplest LNT-DPF system; the soot oxidation was also higher (i.e., hybrid system $>$ LNT /DPF > bare DPF > SCR/DPF). The reasons of such high activity were the use of $\mathrm{NO}_{2}$ and $\mathrm{NH}_{3}$, formed in the LNT-DPF, as reductants for SCR-DPF; moreover, the $\mathrm{NO}_{\mathrm{x}}$ conversion on SCR-DPF was increased by the occurrence of the HC-SCR process [146].

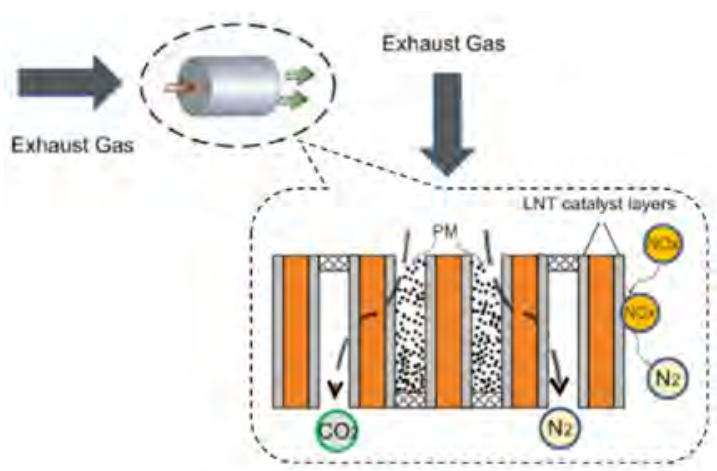

(a) LNT/DPF system.

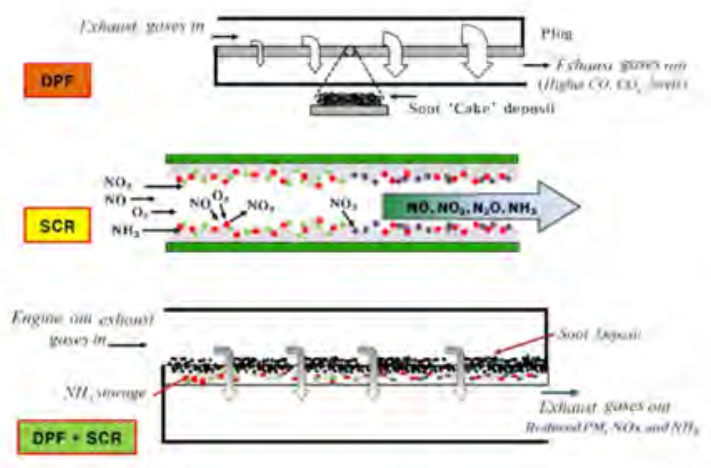

(b) SCR/DPF system.

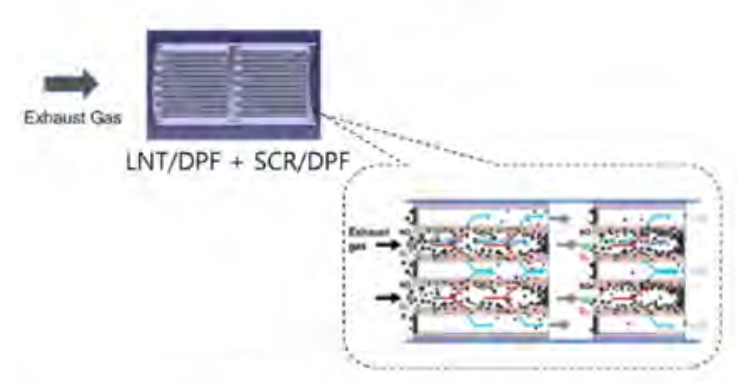

(c) LNT/DPF + SCR/DPF hybrid system.

Figure 22. Fundamental principles of emission reduction in after-treatment systems: (a) LNT/DPF system, (b) SCR/DPF system, and (c) LNT/DPF and SCR/DPF hybrid system. Adapted with permission from ref. [146]. Copyright 2018 Elsevier. 
Finally, to get consistently low $\mathrm{NO}_{x}$ and particulate emissions across a wide range of operating conditions, an LNT system was combined with a dual SCR one. Low-load $\mathrm{NO}_{x}$ control was achieved by the LNT in combination with a close-coupled SCRoF, while high load conditions were covered by an underfloor SCR system fed by a second AdBlue ${ }^{\circledR}$ injector. An advanced control strategy was implemented to ensure optimal interactions between all emission control functionalities. This integrated LNT and active SCR approach to optimize the contribution of each emission control component allowed the system to maintain a high $\mathrm{NO}_{x}$ conversion efficiency of above $84 \%$ during the dedicated urban and motorway driving conditions. Each aftertreatment component (LNT, close-coupled SCR/SCRoF, and underfloor SCR) contributed to achieving the consistently low $\mathrm{NO}_{\mathrm{x}}$ emissions [147].

\section{Conclusions}

In this review, a literature analysis demonstrated that combining the functions of SCR and/or of LNT with the DPF provides the opportunity in light-to-heavy-duty applications for design and packaging flexibility, improved thermal management, and the reduction of the aftertreatment system volume, mass, and cost. This integration can be achieved by using those devices in series or by washcoating the SCR (or LNT) catalyst on and/or in the diesel particulate filter substrate wall.

An SCR/DPF (SCRoF) system integrated over the same device enables significant cost- and size-saving and simultaneously enhances $\mathrm{NO}_{\mathrm{x}}$ conversion due to shorter cold start emissions. The SCR reaction and soot oxidation are competitive for $\mathrm{NO}_{2}$, and the soot oxidation is consequently inhibited and accumulates faster in comparison to the separate CDPF and SCR configuration. This makes the SCRoF implementation more suitable in LDD applications where active soot regeneration is implemented. The current solutions include the engineered coating of the SCR catalyst on the downstream region of the SCRoF to partially decouple the SCR and soot oxidation reaction via spatial distancing and to increase the $\mathrm{NO}_{2} / \mathrm{NO}_{x}$ ratio above 0.5 before to the SCRoF. These are partial solutions that only mitigate the issue of soot accumulation, and comprehensive solutions are needed. The participation of $\mathrm{NO}_{x}$ in soot oxidation is limited, and novel solutions include the addition of a catalyst for $\mathrm{O}_{2}$-mediated soot oxidation over the SCRoF. In this case, it is important to avoid $\mathrm{NH}_{3}$ oxidation over the added soot oxidation catalyst, which could decrease $\mathrm{NO}_{x}$ conversion and selectivity. The use of doped Ce-based catalysts for simultaneous soot oxidation and SCR reactions appears promising. It is unlikely that a single solution for the issue of soot accumulation can be found. Rather, a holistic approach that considers the overall aftertreatment system is necessary. Improving the DOC and thereby the $\mathrm{NO}_{2} / \mathrm{NO}_{x}$ ratio, controlling the urea dosing, and controlling engine mapping for operating in low-soot combustion regimes can lead to better SCRoF functionality. Other common challenges for the SCR reaction include:

- The improvement of $\mathrm{NO}_{\mathrm{x}}$ conversion under $200{ }^{\circ} \mathrm{C}$, with particular concern for the management of $\mathrm{NH}_{4} \mathrm{NO}_{3}$ deposition and the enhancement of the urea decomposition.

- The reduction of $\mathrm{N}_{2} \mathrm{O}$ emissions, which are expected to be regulated in the future for the automotive sector.

- The enhancement of hydrothermal stability and resistance towards poisoning by hydrocarbons and $\mathrm{SO}_{2}$.

Recent publications have demonstrated that despite the complexity of the system, the use of combined technologies, like LNT and SCR, has many advantages, such as greater $\mathrm{NO}_{x}$ conversion, optimized ammonia management, and improved fuel-saving due to the lower amount of reductants required in the reaction with $\mathrm{NO}_{\mathrm{x}}$. Furthermore, costs can potentially be reduced by reducing the size of the precious metal-containing LNT catalyst and eliminating the need for onboard urea storage and delivery systems for the SCR catalyst. However, in this hybrid system, $\mathrm{NO}_{x}$ conversion performance is mainly controlled by the LNT behavior in terms of $\mathrm{NO}_{x}$ adsorption capacity and $\mathrm{NH}_{3}$ formation. 
Author Contributions: Conceptualization, F.M.; writing-original draft preparation, F.M. and L.C.; writing-review and editing, F.M., L.C. and F.A.D.; supervision, F.A.D. All authors contributed to the discussion. All authors have read and agreed to the published version of the manuscript.

Funding: This research received no external funding.

Conflicts of Interest: The authors declare no conflict of interest.

\section{List of Abbreviations}

$\begin{array}{ll}\text { ASC } & \text { Ammonia slip catalyst } \\ \text { C CRT } & \text { Catalyzed continuous regenerating trap } \\ \text { CDPF } & \text { Catalyzed diesel particulate filter } \\ \text { CHA } & \text { Chabazite } \\ \text { CRT } & \text { Continuous regenerating trap } \\ \text { D-CAT } & \text { Diesel Clean Advanced Technology } \\ \text { DOC } & \text { Diesel oxidation catalyst } \\ \text { DPF } & \text { Diesel particulate filter } \\ \text { DPNR } & \text { Diesel Particulate } \mathrm{NO}_{\mathrm{x}} \text { Reduction } \\ \text { EPA } & \text { Environmental Protection Agency } \\ \text { FTIR } & \text { Fourier-transform infrared } \\ \text { HC } & \text { Hydrocarbon } \\ \text { HDD } & \text { Heavy-duty diesel } \\ \text { KCP } & \text { K/CeO } 2-\text { PrO } \\ \text { LDD } & \text { Light-duty diesel } \\ \text { LNT } & \text { Lean } \mathrm{NO}_{\mathrm{x}} \text { Trap } \\ \text { NSR } & \mathrm{NO}_{\mathrm{x}} \text { storage reduction } \\ \text { PGM } & \text { Platinum group metal } \\ \text { PM } & \text { Particulate matter } \\ \text { PNA } & \text { Passive } \mathrm{NO}_{\mathrm{x}} \text { adsorber } \\ \text { SCR } & \text { Selective catalytic reduction } \\ \text { SCRoF or SCR/DPF } & \mathrm{SCR}_{-} \text {-on-Filter } \\ \text { THC } & \text { Total hydrocarbon } \\ \text { VWT } & \mathrm{V}_{2} \mathrm{O}_{5}-\mathrm{WO}_{3} / \text { TiO } \\ \text { WLTP } & \text { Worldwide harmonized Light Vehicles Test Procedure }\end{array}$

\section{References}

1. Saxena, P.; Naik, V. Air Pollution: Sources, Impacts and Controls; CABI: Boston, MA, USA, 2019.

2. Franklin, B.A.; Brook, R.; Arden Pope, C. Air pollution and cardiovascular disease. Curr. Probl. Cardiol. 2015, 40, 207-238. [CrossRef] [PubMed]

3. Hooftman, N.; Messagie, M.; Van Mierlo, J.; Coosemans, T. A review of the European passenger car regulations-Real driving emissions vs local air quality. Renew. Sustain. Energy Rev. 2018, 86, 1-21. [CrossRef]

4. Bielaczyc, P.; Woodburn, J. Trends in Automotive Emission Legislation: Impact on LD Engine Development, Fuels, Lubricants and Test Methods: A Global View, with a Focus on WLTP and RDE Regulations. Emiss. Control Sci. Technol. 2019, 5, 86-98. [CrossRef]

5. Mock, A.P.; Kühlwein, J.; Tietge, U.; Franco, V.; Bandivadekar, A. The 'WLTP'—How a new cars ' test procedure will affect fuel consumption values in Europe and worldwide. ICCT White Pap. 2014, 1-24. [CrossRef]

6. Wittka, T.; Holderbaum, B.; Dittmann, P.; Pischinger, S. Experimental Investigation of Combined LNT + SCR Diesel Exhaust Aftertreatment. Emiss. Control Sci. Technol. 2015, 1, 167-182. [CrossRef]

7. Joshi, A. Progress and outlook on gasoline vehicle after treatment systems. Johnson Matthey Technol. Rev. 2017, 61, 311-325. [CrossRef]

8. Lambert, C.K. Current state of the art and future needs for automotive exhaust catalysis. Nat. Catal. 2019, 2, 554-557. [CrossRef]

9. Twigg, M.V. Rôles of catalytic oxidation in control of vehicle exhaust emissions. Catal. Today 2006, 117, 407-418. [CrossRef]

10. Winkler, S.L.; Anderson, J.E.; Garza, L.; Ruona, W.C.; Vogt, R.; Wallington, T.J. Vehicle criteria pollutant (PM, NOx, CO, HCs) emissions: How low should we go? Clim. Atmos. Sci. 2018, 1, 26. [CrossRef]

11. Suarez-Bertoa, R.; Valverde, V.; Pavlovic, J.; Clairotte, M.; Selleri, T.; Franco, V.; Kregar, Z.; Astorga, C. On-road emissions of Euro 6d-TEMP passenger cars on Alpine routes during the winter period. Environ. Sci. Atmos. 2021, 1, 125-139. [CrossRef]

12. Parks, J.E. Less costly catalysts for controlling engine emissions. Science 2010, 327, 1584-1585. [CrossRef] [PubMed]

13. Forzatti, P.; Lietti, L.; Castoldi, L. Storage and Reduction of NO x over LNT Catalysts. Catal. Lett. 2015, 145, 483-504. [CrossRef] 
14. Lietti, L.; Artioli, N.; Righini, L.; Castoldi, L.; Forzatti, P. Pathways for $\mathrm{N}_{2}$ and $\mathrm{N}_{2} \mathrm{O}$ formation during the reduction of $\mathrm{NO} x$ over $\mathrm{Pt}-\mathrm{Ba} / \mathrm{Al}_{2} \mathrm{O}_{3}$ LNT catalysts investigated by labeling isotopic experiments. Ind. Eng. Chem. Res. 2012, 51, 7597-7605. [CrossRef]

15. Johnson, T.V. Review of Vehicular Emissions Trends. SAE Int. J. Engines 2015, 8. [CrossRef]

16. Heck, R.M.; Farrauto, R.J.; Gulati, S.T. Catalytic Air Pollution Control: Commercial Technology: Third Edition; John Wiley \& Sons, Inc.: Hoboken, NJ, USA, 2012.

17. Heeb, N.V.; Saxer, C.J.; Forss, A.M.; Brühlmann, S. Trends of NO-, $\mathrm{NO}_{2-}^{-}$, and $\mathrm{NH}_{3}$-emissions from gasoline-fueled Euro-3- to Euro-4-passenger cars. Atmos. Environ. 2008, 42, 2543-2554. [CrossRef]

18. Brandenberger, S.; Kröcher, O.; Tissler, A.; Althoff, R. The state of the art in selective catalytic reduction of NOx by ammonia using metal-exchanged zeolite catalysts. Catal. Rev. Sci. Eng. 2008, 50, 492-531. [CrossRef]

19. Busca, G.; Lietti, L.; Ramis, G.; Berti, F. Chemical and mechanistic aspects of the selective catalytic reduction of $\mathrm{NO}(\mathrm{x})$ by ammonia over oxide catalysts: A review. Appl. Catal. B Environ. 1998, 18, 1-36. [CrossRef]

20. Václavík, M.; Plachá, M.; Kočí, P.; Svoboda, M.; Hotchkiss, T.; Novák, V.; Thompsett, D. Structure characterisation of catalytic particulate filters for automotive exhaust gas aftertreatment. Mater. Charact. 2017, 134, 311-318. [CrossRef]

21. Hazlett, M.J.; Epling, W.S. Heterogeneous catalyst design: Zoned and layered catalysts in diesel vehicle aftertreatment monolith reactors. Can. J. Chem. Eng. 2019, 97, 188-206. [CrossRef]

22. Martinovic, F.; Andana, T.; Piumetti, M.; Armandi, M.; Bonelli, B.; Deorsola, F.A.; Bensaid, S.; Pirone, R. Simultaneous improvement of ammonia mediated NOx SCR and soot oxidation for enhanced SCR-on-Filter application. Appl. Catal. A Gen. 2020, 596, 117538. [CrossRef]

23. Tang, W.; Youngren, D.; Santa, M.M.; Kumar, S. On-engine investigation of SCR on filters (SCRoF) for HDD passive applications. SAE Int. J. Engines 2013, 6, 862-872. [CrossRef]

24. Rappé, K.G. Integrated selective catalytic reduction-diesel particulate filter aftertreatment: Insights into pressure drop, NOx conversion, and passive soot oxidation behavior. Ind. Eng. Chem. Res. 2014, 53, 17547-17557. [CrossRef]

25. Emran, A.; Ehrly, M.; Sandhu, R.; Santhoji Kale, R.; Sharma, V.; Rathod, D. Optimized Exhaust After-Treatment System Solution for Indian Heavy Duty City Bus Application-The Challenges Involved and the Right Approach to Meet Future BS VI Emission Legislations and Real World Driving Emissions. In Proceedings of the Symposium on International Automotive Technology 2019, Pune, India, 16-19 January 2019.

26. Lee, J.H.; Paratore, M.J.; Brown, D.B. Evaluation of Cu-based SCR/DPF technology for diesel exhaust emission control. SAE Int. J. Fuels Lubr. 2009, 1, 96-101. [CrossRef]

27. Wolff, T.; Deinlein, R.; Christensen, H.; Larsen, L. Dual layer coated high porous SiC-A new concept for SCR integration into DPF. SAE Int. J. Mater. Manuf. 2014, 7, 671-681. [CrossRef]

28. Wang, Y.; Obuchi, Y.; Zhang, J.; Tracy, I.; Wong, V. Experiments and Analyses on Stability/Mid-Channel Collapse of Ash-Deposit Wall Layers and Pre-Mature Clogging of Diesel Particulate Filters; SAE Technical Papers; SAE International: Warrendale, PA, USA, 2019.

29. Chen, H.Y.; Wei, Z.; Kollar, M.; Gao, F.; Wang, Y.; Szanyi, J.; Peden, C.H.F. A comparative study of N2O formation during the selective catalytic reduction of NOx with NH3 on zeolite supported Cu catalysts. J. Catal. 2015, 329, 490-498. [CrossRef]

30. Leistner, K.; Mihai, O.; Wijayanti, K.; Kumar, A.; Kamasamudram, K.; Currier, N.W.; Yezerets, A.; Olsson, L. Comparison of $\mathrm{Cu}$ /BEA, Cu/SSZ-13 and Cu/SAPO-34 for ammonia-SCR reactions. Catal. Today 2015, 258, 49-55. [CrossRef]

31. Zhang, S.; Pang, L.; Chen, Z.; Ming, S.; Dong, Y.; Liu, Q.; Liu, P.; Cai, W.; Li, T. Cu/SSZ-13 and Cu/SAPO-34 catalysts for deNOx in diesel exhaust: Current status, challenges, and future perspectives. Appl. Catal. A Gen. 2020, 607, 117855. [CrossRef]

32. Gao, F.; Mei, D.; Wang, Y.; Szanyi, J.; Peden, C.H.F. Selective Catalytic Reduction over Cu/SSZ-13: Linking Homo- and Heterogeneous Catalysis. J. Am. Chem. Soc. 2017, 139, 4935-4942. [CrossRef]

33. Shan, Y.; Du, J.; Zhang, Y.; Shan, W.; Shi, X.; Yu, Y.; Zhang, R.; Meng, X.; Xiao, F.-S.; He, H. Selective catalytic reduction of NO x with NH3: Opportunities and challenges of Cu-based small-pore zeolites. Natl. Sci. Rev. 2021. [CrossRef]

34. Kim, Y.J.; Kim, P.S.; Kim, C.H. Deactivation mechanism of $\mathrm{Cu} /$ Zeolite SCR catalyst under high-temperature rich operation condition. Appl. Catal. A Gen. 2019, 569, 175-180. [CrossRef]

35. Ryu, T.; Kim, H.; Hong, S.B. Nature of active sites in Cu-LTA NH3-SCR catalysts: A comparative study with Cu-SSZ-13. Appl. Catal. B Environ. 2019, 245, 513-521. [CrossRef]

36. Martín, N.; Boruntea, C.R.; Moliner, M.; Corma, A. Efficient synthesis of the Cu-SSZ-39 catalyst for DeNOx applications. Chem. Commun. 2015, 51, 11030-11033. [CrossRef] [PubMed]

37. Shan, Y.; Shan, W.; Shi, X.; Du, J.; Yu, Y.; He, H. A comparative study of the activity and hydrothermal stability of Al-rich Cu-SSZ-39 and Cu-SSZ-13. Appl. Catal. B Environ. 2020, 264, 118511. [CrossRef]

38. Fahami, A.R.; Günter, T.; Doronkin, D.E.; Casapu, M.; Zengel, D.; Vuong, T.H.; Simon, M.; Breher, F.; Kucherov, A.V.; Brückner, A.; et al. The dynamic nature of $\mathrm{Cu}$ sites in Cu-SSZ-13 and the origin of the seagull NO: $\mathrm{X}$ conversion profile during NH3-SCR. React. Chem. Eng. 2019, 4, 1000-1018. [CrossRef]

39. Daya, R.; Joshi, S.Y.; Luo, J.; Dadi, R.K.; Currier, N.W.; Yezerets, A. On kinetic modeling of change in active sites upon hydrothermal aging of Cu-SSZ-13. Appl. Catal. B Environ. 2020, 263, 118368. [CrossRef]

40. Gao, F.; Peden, C.H.F. Recent progress in atomic-level understanding of Cu/SSZ-13 selective catalytic reduction catalysts. Catalysts 2018, 8, 140 .

41. Johansen, K.; Widd, A.; Zuther, F.; Viecenz, H. Passive NO2 Regeneration and NOx Conversion for DPF with an Integrated Vanadium SCR Catalyst; SAE Technical Papers; SAE International: Warrendale, PA, USA, 2016. 
42. Johansen, K.; Bentzer, H.; Kustov, A.; Larsen, K.; Janssens, T.V.W.; Barfod, R.G. Integration of Vanadium and Zeolite Type SCR Functionality into DPF in Exhaust Aftertreatment Systems-Advantages and Challenges; SAE Technical Papers; SAE International: Warrendale, PA, USA, 2014.

43. Xi, Y.; Ottinger, N.A.; Liu, Z.G. Simulation of exotherms from the oxidation of accumulated carbonaceous species over a VSCR catalyst. React. Chem. Eng. 2019, 4, 1090-1102. [CrossRef]

44. Marchitti, F.; Nova, I.; Tronconi, E. Experimental study of the interaction between soot combustion and NH3-SCR reactivity over a Cu-Zeolite SDPF catalyst. Catal. Today 2016, 267, 110-118. [CrossRef]

45. Martinovic, F.; Andana, T.; Deorsola, F.A.; Bensaid, S.; Pirone, R. On-Filter Integration of Soot Oxidation and Selective Catalytic Reduction of NOx with NH3 by Selective Two Component Catalysts. Catal. Lett. 2020, 150, 573-585. [CrossRef]

46. Watling, T.C.; Ravenscroft, M.R.; Avery, G. Development, validation and application of a model for an SCR catalyst coated diesel particulate filter. Catal. Today 2012, 188, 32-41. [CrossRef]

47. Park, S.Y.; Narayanaswamy, K.; Schmieg, S.J.; Rutland, C.J. A model development for evaluating soot-NOx interactions in a blended 2-way diesel particulate filter/selective catalytic reduction. Ind. Eng. Chem. Res. 2012, 51, 15582-15592. [CrossRef]

48. Karamitros, D.; Koltsakis, G. Model-based optimization of catalyst zoning on SCR-coated particulate filters. Chem. Eng. Sci. 2017, 173, 514-524. [CrossRef]

49. Stewart, M.L.; Kamp, C.J.; Gao, F.; Wang, Y.; Engelhard, M.H. Coating Distribution in a Commercial SCR Filter. Emiss. Control Sci. Technol. 2018, 4, 260-270. [CrossRef]

50. Bensaid, S.; Balakotaiah, V.; Luss, D. Simulation of NOx and soot abatement with Cu-Cha and Fe-ZSM5 catalysts. AIChE J. 2017, 63, 238-248. [CrossRef]

51. Chen, K.; Martirosyan, K.S.; Luss, D. Transient temperature rise during regeneration of diesel particulate filters. Chem. Eng. J. 2011, 176-177, 144-150. [CrossRef]

52. Ballinger, T.; Cox, J.; Konduru, M.; De, D.; Manning, W.; Andersen, P. Evaluation of SCR catalyst technology on diesel particulate filters. SAE Int. 2009, 2, 369-374. [CrossRef]

53. Bensaid, S.; Caroca, C.J.; Russo, N.; Fino, D. Detailed investigation of non-catalytic DPF regeneration. Can. J. Chem. Eng. 2011, 89, 401-407. [CrossRef]

54. Choi, S.; Oh, K.C.; Lee, C.B. The effects of filter porosity and flow conditions on soot deposition/oxidation and pressure drop in particulate filters. Energy 2014, 77, 327-337. [CrossRef]

55. Nanba, T.; Masukawa, S.; Abe, A.; Uchisawa, J.; Obuchi, A. Quantitative analysis of active oxygen for soot oxidation over Ag/ZrO 2: Characterization with temperature-programmed reduction by $\mathrm{NH}_{3}$. Appl. Catal. B Environ. 2012, 123-124, 351-356. [CrossRef]

56. Mytareva, A.I.; Bokarev, D.A.; Baeva, G.N.; Krivoruchenko, D.S.; Belyankin, A.Y.; Stakheev, A.Y. Composite catalysts for selective catalytic reduction of NOx and oxidation of residual $\mathrm{NH}_{3}$. Pet. Chem. 2016, 56, 211-216. [CrossRef]

57. Stakheev, A.Y.; Baeva, G.N.; Bragina, G.O.; Teleguina, N.S.; Kustov, A.L.; Grill, M.; Thøgersen, J.R. Integrated DeNO x-DeSoot catalytic systems with improved low-temperature performance. Top. Catal. 2013, 56, 427-433. [CrossRef]

58. Salazar, M.; Hoffmann, S.; Tkachenko, O.P.; Becker, R.; Grünert, W. Hybrid catalysts for the selective catalytic reduction of NO by NH3: The influence of component separation on the performance of hybrid systems. Appl. Catal. B Environ. 2016, 182, 213-219. [CrossRef]

59. Liu, Z.; Feng, X.; Zhou, Z.; Feng, Y.; Li, J. Ce-Sn binary oxide catalyst for the selective catalytic reduction of $\mathrm{NOx}_{\text {by }} \mathrm{NH}_{3}$. Appl. Surf. Sci. 2018, 428, 526-533. [CrossRef]

60. Li, X.; Li, Y.; Deng, S.A.; Rong, T. A Ce-Sn-Ox catalyst for the selective catalytic reduction of NOx with $\mathrm{NH}_{3}$. Catal. Commun. 2013, 40, 47-50. [CrossRef]

61. Wang, D.; Zhang, C.; Xie, Y.; Pan, Z.; Xue, X.; Zhang, R. A study on the catalytic oxidation of soot by Sn-Ce composite oxides: Adsorbed oxygen and defect sites synergistically enhance catalytic activity. New J. Chem. 2019, 43, 17423-17432. [CrossRef]

62. Zhang, S.; Zhang, B.; Liu, B.; Sun, S. A review of Mn-containing oxide catalysts for low temperature selective catalytic reduction of NO: X with NH3: Reaction mechanism and catalyst deactivation. RSC Adv. 2017, 7, 26226-26242. [CrossRef]

63. Tan, J.; Wei, Y.; Sun, Y.; Liu, J.; Zhao, Z.; Song, W.; Li, J.; Zhang, X. Simultaneous removal of NOx and soot particulates from diesel engine exhaust by 3DOM Fe-Mn oxide catalysts. J. Ind. Eng. Chem. 2018, 63, 84-94. [CrossRef]

64. Heo, I.; Sung, S.; Park, M.B.; Chang, T.S.; Kim, Y.J.; Cho, B.K.; Hong, S.B.; Choung, J.W.; Nam, I.S. Effect of Hydrocarbon on DeNOx Performance of Selective Catalytic Reduction by a Combined Reductant over Cu-Containing Zeolite Catalysts. ACS Catal. 2019, 9, 9800-9812. [CrossRef]

65. Luo, J.Y.; Yezerets, A.; Henry, C.; Hess, H.; Kamasamudram, K.; Chen, H.Y.; Epling, W.S. Hydrocarbon Poisoning of Cu-Zeolite SCR Catalysts; SAE Technical Papers; SAE International: Warrendale, PA, USA, 2012.

66. Ye, Q.; Wang, L.; Yang, R.T. Activity, propene poisoning resistance and hydrothermal stability of copper exchanged chabazite-like zeolite catalysts for SCR of NO with ammonia in comparison to Cu/ZSM-5. Appl. Catal. A Gen. 2012, 427-428, 24-34. [CrossRef]

67. Wang, J.; Ji, Y.; He, Z.; Crocker, M.; Dearth, M.; McCabe, R.W. A non-NH 3 pathway for NOx conversion in coupled LNT-SCR systems. Appl. Catal. B Environ. 2012, 111-112, 562-570. [CrossRef]

68. Cavataio, G.; Warner, J.R.; Girard, J.W.; Ura, J.; Dobson, D.; Lambert, C.K. Laboratory study of soot, propylene, and diesel fuel impact on zeolite-based SCR filter catalysts. SAE Int. J. Fuels Lubr. 2009, 2, 342-368. [CrossRef]

69. Stratakis, G.A.; Konstantas, G.S.; Stamatelos, A.M. Experimental investigation of the role of soot volatile organic fraction in the regeneration of diesel filters. Proc. Inst. Mech. Eng. Part D J. Automob. Eng. 2003, 217, 307-317. [CrossRef] 
70. Martinovic, F.; Deorsola, F.A.; Armandi, M.; Bonelli, B.; Palkovits, R.; Bensaid, S.; Pirone, R. Composite Cu-SSZ-13 and CeO2-SnO2 for enhanced NH3-SCR resistance towards hydrocarbon deactivation. Appl. Catal. B Environ. 2021, 282. [CrossRef]

71. Zhao, Q.; Chen, B.; Bai, Z.; Yu, L.; Crocker, M.; Shi, C. Hybrid catalysts with enhanced C3H6 resistance for $\mathrm{NH}_{3}-\mathrm{SCR}$ of $\mathrm{NOx}$ Appl. Catal. B Environ. 2019, 242, 161-170. [CrossRef]

72. Yu, R.; Zhao, Z.; Shi, C.; Zhang, W. Insight into the Synergic Effect of Fe-SSZ-13 Zeolite and FeMnTiZrO x Catalyst with Enhanced Reactivity in NH 3 -SCR of NO x. J. Phys. Chem. C 2019, 123, 2216-2227. [CrossRef]

73. Bernhard, A.M.; Peitz, D.; Elsener, M.; Schildhauer, T.; Kröcher, O. Catalytic urea hydrolysis in the selective catalytic reduction of $\mathrm{NO}$ x: Catalyst screening and kinetics on anatase $\mathrm{TiO}_{2}$ and $\mathrm{ZrO}_{2}$. Catal. Sci. Technol. 2013, 3, 942-951. [CrossRef]

74. Seneque, M.; Courtois, X.; Can, F.; Duprez, D. Direct Comparison of Urea-SCR and NH3-SCR Activities Over Acidic Oxide and Exchanged Zeolite Prototype Powdered Catalysts. Top. Catal. 2016, 59, 938-944. [CrossRef]

75. Ma, Y.; Wu, X.; Zhang, J.; Ran, R.; Weng, D. Urea-related reactions and their active sites over Cu-SAPO-34: Formation of NH3 and conversion of HNCO. Appl. Catal. B Environ. 2018, 227, 198-208. [CrossRef]

76. Peitz, D.; Bernhard, A.; Kröcher, O. Ammonia Storage and Release in SCR Systems for Mobile Applications Urea-SCR Technology for deNOx After Treatment of Diesel Exhausts; Springer: New York, NY, USA, 2014; pp. 485-506.

77. Cho, C.P.; Pyo, Y.D.; Jang, J.Y.; Kim, G.C.; Shin, Y.J. NOx reduction and $\mathrm{N}_{2} \mathrm{O}$ emissions in a diesel engine exhaust using Fe-zeolite and vanadium based SCR catalysts. Appl. Therm. Eng. 2017, 110, 18-24. [CrossRef]

78. Jung, Y.; Shin, Y.J.; Pyo, Y.D.; Cho, C.P.; Jang, J.; Kim, G. NOx and $\mathrm{N}_{2} \mathrm{O}$ emissions over a Urea-SCR system containing both V2O5-WO3/TiO2 and Cu-zeolite catalysts in a diesel engine. Chem. Eng. J. 2017, 326, 853-862. [CrossRef]

79. Liu, Q.; Bian, C.; Ming, S.; Guo, L.; Zhang, S.; Pang, L.; Liu, P.; Chen, Z.; Li, T. The opportunities and challenges of iron-zeolite as $\mathrm{NH}_{3}$-SCR catalyst in purification of vehicle exhaust. Appl. Catal. A Gen. 2020, 607, 117865. [CrossRef]

80. Girard, J.W.; Montreuil, C.; Kim, J.; Cavataio, G.; Lambert, C. Technical advantages of vanadium SCR systems for diesel NOx control in emerging markets. SAE Int. J. Fuels Lubr. 2009, 1, 488-494. [CrossRef]

81. Zhang, D.; Yang, R.T. $\mathrm{N}_{2} \mathrm{O}$ Formation Pathways over Zeolite-Supported Cu and Fe Catalysts in $\mathrm{NH}_{3}-\mathrm{SCR}$. Energy Fuels 2018, 32, 2170-2182. [CrossRef]

82. Metkar, P.S.; Harold, M.P.; Balakotaiah, V. Experimental and kinetic modeling study of $\mathrm{NH}_{3}-\mathrm{SCR}$ of NOx on Fe-ZSM-5, Cuchabazite and combined Fe- and Cu-zeolite monolithic catalysts. Chem. Eng. Sci. 2013, 87, 51-66. [CrossRef]

83. Iwasaki, M.; Shinjoh, H. A comparative study of "standard", "fast" and " $\mathrm{nO}_{2}$ " SCR reactions over Fe/zeolite catalyst. Appl. Catal. A Gen. 2010, 390, 71-77. [CrossRef]

84. Kamasamudram, K.; Henry, C.; Currier, N.; Yezerets, A. N2O Formation and Mitigation in Diesel Aftertreatment Systems. SAE Int. J. Engines 2012, 5, 688-698. [CrossRef]

85. Ruggeri, M.P.; Luo, J.; Nova, I.; Tronconi, E.; Kamasamudram, K.; Yezerets, A. Novel method of ammonium nitrate quantification in SCR catalysts. Catal. Today 2018, 307, 48-54. [CrossRef]

86. Bendrich, M.; Scheuer, A.; Hayes, R.E.; Votsmeier, M. Increased SCR performance of Cu-CHA due to ammonium nitrate buffer: Experiments with oscillating NO/NO2 ratios and application to real driving cycles. Appl. Catal. B Environ. 2020, $270,118763$. [CrossRef]

87. Mihai, O.; Tamm, S.; Stenfeldt, M.; Olsson, L. The effect of soot on ammonium nitrate species and NO2 selective catalytic reduction over Cu-zeolite catalyst-coated particulate filter. Philos. Trans. R. Soc. A Math. Phys. Eng. Sci. 2016, 374, 20150086. [CrossRef]

88. Mihai, O.; Tamm, S.; Stenfeldt, M.; Wang-Hansen, C.; Olsson, L. Evaluation of an Integrated Selective Catalytic Reduction-Coated Particulate Filter. Ind. Eng. Chem. Res. 2015, 54, 11779-11791. [CrossRef]

89. Peng, B.; Rappé, K.G.; Cui, Y.; Gao, F.; Szanyi, J.; Olszta, M.J.; Walter, E.D.; Wang, Y.; Holladay, J.D.; Goffe, R.A. Enhancement of high-temperature selectivity on Cu-SSZ-13 towards NH3-SCR reaction from highly dispersed $\mathrm{ZrO}_{2}$. Appl. Catal. B Environ. 2020, 263, 118359. [CrossRef]

90. Fan, J.; Ning, P.; Wang, Y.; Song, Z.; Liu, X.; Wang, H.; Wang, J.; Wang, L.; Zhang, Q. Significant promoting effect of Ce or La on the hydrothermal stability of Cu-SAPO-34 catalyst for NH3-SCR reaction. Chem. Eng. J. 2019, 369, 908-919. [CrossRef]

91. Usui, T.; Liu, Z.; Ibe, S.; Zhu, J.; Anand, C.; Igarashi, H.; Onaya, N.; Sasaki, Y.; Shiramata, Y.; Kusamoto, T.; et al. Improve the Hydrothermal Stability of Cu-SSZ-13 Zeolite Catalyst by Loading a Small Amount of Ce. ACS Catal. 2018, 8, 9165-9173. [CrossRef]

92. Gao, F.; Wang, Y.; Washton, N.M.; Kollár, M.; Szanyi, J.; Peden, C.H.F. Effects of Alkali and Alkaline Earth Cocations on the Activity and Hydrothermal Stability of Cu/SSZ-13 NH3-SCR Catalysts. ACS Catal. 2015, 5, 6780-6791. [CrossRef]

93. Wijayanti, K.; Xie, K.; Kumar, A.; Kamasamudram, K.; Olsson, L. Effect of gas compositions on SO2 poisoning over Cu/SSZ-13 used for NH3-SCR. Appl. Catal. B Environ. 2017, 219, 142-154. [CrossRef]

94. Yu, R.; Zhao, Z.; Huang, S.; Zhang, W. Cu-SSZ-13 zeolite-metal oxide hybrid catalysts with enhanced SO2-tolerance in the NH3-SCR of NOx. Appl. Catal. B Environ. 2020, 269, 118825. [CrossRef]

95. Mesilov, V.V.; Bergman, S.L.; Dahlin, S.; Xiao, Y.; Xi, S.; Zhirui, M.; Xu, L.; Chen, W.; Pettersson, L.J.; Bernasek, S.L. Differences in oxidation-reduction kinetics and mobility of $\mathrm{Cu}$ species in fresh and SO2-poisoned Cu-SSZ-13 catalysts. Appl. Catal. B Environ. 2021, 284, 119756. [CrossRef]

96. Kumar, A.; Smith, M.A.; Kamasamudram, K.; Currier, N.W.; Yezerets, A. Chemical deSOx: An effective way to recover Cu-zeolite SCR catalysts from sulfur poisoning. Catal. Today 2016, 267, 10-16. [CrossRef] 
97. Hammershøi, P.S.; Vennestrøm, P.N.R.; Falsig, H.; Jensen, A.D.; Janssens, T.V.W. Importance of the Cu oxidation state for the SO2-poisoning of a Cu-SAPO-34 catalyst in the NH3-SCR reaction. Appl. Catal. B Environ. 2018, 236, 377-383. [CrossRef]

98. Yoshida, K.; Makino, S.; Sumiya, S.; Muramatsu, G.; Helferich, R. Simultaneous Reduction of NOx and Particulate Emissions from Diesel Engine Exhaust; SAE Technical Papers; SAE International: Warrendale, PA, USA, 1989.

99. Nakatani, K.; Hirota, S.; Takeshima, S.; Itoh, K.; Tanaka, T.; Dohmae, K. Simultaneous PM and NOx Reduction System for Diesel Engines; SAE Technical Papers; SAE International: Warrendale, PA, USA, 2002.

100. Liu, C.; Lietti, L.; Castoldi, L.; Matarrese, R.; Forzatti, P. Chapter 11: Combined LNT-SCR Catalysts for NOx Reduction from Lean Exhaust Gas. In RSC Catalysis Series; Royal Society of Chemistry: London, UK, 2018; pp. 321-352.

101. Kočí, P.; Plát, F.; Štěpánek, J.; Bártová, Š.; Marek, M.; Kubíček, M.; Schmeißer, V.; Chatterjee, D.; Weibel, M. Global kinetic model for the regeneration of $\mathrm{NOx}$ storage catalyst with $\mathrm{CO}, \mathrm{H}_{2}$ and $\mathrm{C}_{3} \mathrm{H}_{6}$ in the presence of $\mathrm{CO}_{2}$ and $\mathrm{H}_{2} \mathrm{O}$. Catal. Today 2009, 147, 257-264. [CrossRef]

102. Ting, A.W.L.; Li, M.; Harold, M.P.; Balakotaiah, V. Fast cycling in a non-isothermal monolithic lean NOx trap using $\mathrm{H}_{2}$ as reductant: Experiments and modeling. Chem. Eng. J. 2017, 326, 419-435. [CrossRef]

103. Cortés-Reyes, M.; Herrera, C.; Larrubia, M.Á.; Alemany, L.J. Advance in the scaling up of a hybrid catalyst for NSR-SCR coupled systems under $\mathrm{H}_{2} \mathrm{O}+\mathrm{CO}_{2}$ atmosphere. Catal. Today 2020, 356, 292-300. [CrossRef]

104. Kubiak, L.; Castoldi, L.; Lietti, L.; Andonova, S.; Olsson, L. Mechanistic investigation of the reduction of NOx over Pt-and Rh-based LNT catalysts. Catalysts 2016, 6, 46. [CrossRef]

105. Onrubia-Calvo, J.A.; Pereda-Ayo, B.; Urrutxua, M.; De La Torre, U.; González-Velasco, J.R. Boosting NOx Removal by PerovskiteBased Catalyst in NSR-SCR Diesel Aftertreatment Systems. Ind. Eng. Chem. Res. 2021. [CrossRef]

106. Xu, L.; McCabe, R.W. LNT + in situ SCR catalyst system for diesel emissions control. Catal. Today 2012, 184, 83-94. [CrossRef]

107. Pereda-Ayo, B.; Duraiswami, D.; González-Velasco, J.R. Control of NOx storage and reduction in NSR bed for designing combined NSR-SCR systems. Catal. Today 2011, 172, 66-72. [CrossRef]

108. De La Torre, U.; Pereda-Ayo, B.; González-Velasco, J.R. Cu-zeolite NH 3-SCR catalysts for NO x removal in the combined NSR-SCR technology. Chem. Eng. J. 2012, 207-208, 10-17. [CrossRef]

109. Castoldi, L.; Bonzi, R.; Lietti, L.; Forzatti, P.; Morandi, S.; Ghiotti, G.; Dzwigaj, S. Catalytic behaviour of hybrid LNT/SCR systems: Reactivity and in situ FTIR study. J. Catal. 2011, 282, 128-144. [CrossRef]

110. Lindholm, A.; Sjövall, H.; Olsson, L. Reduction of NOx over a combined NSR and SCR system. Appl. Catal. B Environ. 2010, 98, 112-121. [CrossRef]

111. Forzatti, P.; Lietti, L.; Nova, I.; Tronconi, E. Diesel NOx aftertreatment catalytic technologies: Analogies in LNT and SCR catalytic chemistry. Catal. Today 2010, 151, 202-211. [CrossRef]

112. Can, F.; Courtois, X.; Royer, S.; Blanchard, G.; Rousseau, S.; Duprez, D. An overview of the production and use of ammonia in NSR + SCR coupled system for NOx reduction from lean exhaust gas. Catal. Today 2012, 197, 144-154. [CrossRef]

113. Gandhi, H.S.; Cavataio, J.V.; Hammerle, R.H.; Cheng, Y. Catalyst System for Lean Burn Engines. U.S. Patent US 7,329,629 B2, 12 February 2008.

114. Enderle, C.; Vent, G.; Paule, M. Bluetec Diesel Technology-Clean, Efficient and Powerful; SAE Technical Papers; SAE International: Warrendale, PA, USA, 2008.

115. Bonzi, R.; Lietti, L.; Castoldi, L.; Forzatti, P. NOx removal over a double-bed NSR-SCR reactor configuration. Catal. Today 2010, 151, 376-385. [CrossRef]

116. Corbos, E.C.; Haneda, M.; Courtois, X.; Marecot, P.; Duprez, D.; Hamada, H. Cooperative effect of Pt-Rh/Ba/Al and CuZSM-5 catalysts for NOx reduction during periodic lean-rich atmosphere. Catal. Commun. 2008, 10, 137-141. [CrossRef]

117. Corbos, E.C.; Haneda, M.; Courtois, X.; Marecot, P.; Duprez, D.; Hamada, H. NOx abatement for lean-burn engines under lean-rich atmosphere over mixed NSR-SCR catalysts: Influences of the addition of a SCR catalyst and of the operational conditions. Appl. Catal. A Gen. 2009, 365, 187-193. [CrossRef]

118. De La Torre, U.; Pereda-Ayo, B.; Romero-Sáez, M.; Aranzabal, A.; González-Marcos, M.P.; González-Marcos, J.A.; GonzálezVelasco, J.R. Screening of Fe-Cu-zeolites prepared by different methodology for application in NSR-SCR combined DeNOx systems. Top. Catal. 2013, 56, 215-221. [CrossRef]

119. De-La-Torre, U.; Pereda-Ayo, B.; Moliner, M.; González-Velasco, J.R.; Corma, A. Cu-zeolite catalysts for NOx removal by selective catalytic reduction with $\mathrm{NH} 3$ and coupled to NO storage/reduction monolith in diesel engine exhaust aftertreatment systems. Appl. Catal. B Environ. 2016, 187, 419-427. [CrossRef]

120. Kwak, J.H.; Tran, D.; Szanyi, J.; Peden, C.H.F.; Lee, J.H. The effect of copper loading on the selective catalytic reduction of nitric oxide by ammonia over Cu-SSZ-13. Catal. Lett. 2012, 142, 295-301. [CrossRef]

121. De-La-Torre, U.; Pereda-Ayo, B.; Moliner, M.; González-Marcos, J.A.; Corma, A.; González-Velasco, J.R. Optimal Operating Conditions of Coupled Sequential NOx Storage/Reduction and Cu/CHA Selective Catalytic Reduction Monoliths. Top. Catal. 2017, 60, 30-39. [CrossRef]

122. Urrutxua, M.; Pereda-Ayo, B.; Trandafilovic, L.V.; Olsson, L.; González-Velasco, J.R. Influence of H2, CO, C3H6, and C7H8 as Reductants on DeNOx Behavior of Dual Monoliths for NOx Storage/Reduction Coupled with Selective Catalytic Reduction. Ind. Eng. Chem. Res. 2019, 58, 7001-7013. [CrossRef]

123. Seo, C.K.; Kim, H.; Choi, B.; Lim, M.T.; Lee, C.H.; Lee, C.B. De-NOx characteristics of a combined system of LNT and SCR catalysts according to hydrothermal aging and sulfur poisoning. Catal. Today 2011, 164, 507-514. [CrossRef] 
124. Shakya, B.M.; Harold, M.P.; Balakotaiah, V. Modeling and analysis of dual-layer NOx storage and reduction and selective catalytic reduction monolithic catalyst. Chem. Eng. J. 2014, 237, 109-122. [CrossRef]

125. Zheng, Y.; Liu, Y.; Harold, M.P.; Luss, D. LNT-SCR dual-layer catalysts optimized for lean NOx reduction by H2 and CO. Appl. Catal. B Environ. 2014, 148-149, 311-321. [CrossRef]

126. Nakatsuji, T.; Matsubara, M.; Rouistenmäki, J.; Sato, N.; Ohno, H. A NOx reduction system using ammonia-storage selective catalytic reduction in rich/lean excursions. Appl. Catal. B Environ. 2007, 77, 190-201. [CrossRef]

127. Morita, T.; Suzuki, N.; Satoh, N.; Wada, K.; Ohno, H. Study on Low NOX Emission Control Using Newly Developed Lean NOX Catalyst for Diesel Engines; SAE Technical Papers; SAE International: Warrendale, PA, USA, 2007.

128. Wada, K.; Suzuki, N.; Satoh, N.; Morita, T.; Yamaguchi, S.; Ohno, H. Study on Emission Reducing Method with New Lean NOx Catalyst for Diesel Engines; SAE Technical Papers; SAE International: Warrendale, PA, USA, 2007.

129. Liu, Y.; Harold, M.P.; Luss, D. Coupled NO x storage and reduction and selective catalytic reduction using dual-layer monolithic catalysts. Appl. Catal. B Environ. 2012, 121-122, 239-251. [CrossRef]

130. Xu, L.; McCabe, R.; Tennison, P.; Jen, H.W. Laboratory and Vehicle Demonstration of "2nd-Generation" LNT + in-situ SCR Diesel Emission Control Systems. SAE Int. J. Engines 2011, 4, 158-174. [CrossRef]

131. Zheng, Y.; Li, M.; Wang, D.; Harold, M.P.; Luss, D. Rapid propylene pulsing for enhanced low temperature NOx conversion on combined LNT-SCR catalysts. Catal. Today 2016, 267, 192-201. [CrossRef]

132. Liu, Y.; Zheng, Y.; Harold, M.P.; Luss, D. Lean NOx reduction on LNT-SCR dual-layer catalysts by $\mathrm{H}_{2}$ and CO. Appl. Catal. B Environ. 2013, 132-133, 293-303. [CrossRef]

133. Kim, Y.; Hwang, S.; Lee, J.; Ryou, Y.S.; Lee, H.; Kim, C.H.; Kim, D.H. Comparison of NO x Adsorption/Desorption Behaviors over Pd/CeO 2 and Pd/SSZ-13 as Passive NOx Adsorbers for Cold Start Application. Emiss. Control Sci. Technol. 2019, 5, 172-182. [CrossRef]

134. Khivantsev, K.; Jaegers, N.R.; Kovarik, L.; Prodinger, S.; Derewinski, M.A.; Wang, Y.; Gao, F.; Szanyi, J. Palladium/Beta zeolite passive NOx adsorbers (PNA): Clarification of PNA chemistry and the effects of CO and zeolite crystallite size on PNA performance. Appl. Catal. A Gen. 2019, 569, 141-148. [CrossRef]

135. Wang, A.; Xie, K.; Kumar, A.; Kamasamudram, K.; Olsson, L. Layered Pd/SSZ-13 with Cu/SSZ-13 as PNA - SCR dual-layer monolith catalyst for NOx abatement. Catal. Today 2021, 360, 356-366. [CrossRef]

136. Cooper, B.J.; Thoss, J.E. Role of NO in Diesel Particulate Emission Control; SAE Technical Papers; SAE International: Warrendale, PA, USA, 1989.

137. Stanmore, B.R.; Brilhac, J.F.; Gilot, P. The oxidation of soot: A review of experiments, mechanisms and models. Carbon 2001, 39, 2247-2268. [CrossRef]

138. Castoldi, L. An overview on the catalytic materials proposed for the simultaneous removal of NOx and soot. Materials 2020, 13, 3551. [CrossRef]

139. Schejbal, M.; Štěpánek, J.; Marek, M.; Kočí, P.; Kubíček, M. Modelling of soot oxidation by NO2 in various types of diesel particulate filters. Fuel 2010, 89, 2365-2375. [CrossRef]

140. Schejbal, M.; Štěpánek, J.; Kočí, P.; Marek, M.; Kubíček, M. Sequence of monolithic converters DOC-CDPF-NSRC for lean exhaust gas detoxification: A simulation study. Chem. Eng. Process. Process. Intensif. 2010, 49, 943-952. [CrossRef]

141. Choi, B.; Lee, K.S. LNT/CDPF catalysts for simultaneous removal of NOx and PM from diesel vehicle exhaust. Chem. Eng. J. 2014, 240, 476-486. [CrossRef]

142. Burch, R.; Fornasiero, P.; Southward, B.W.L. An investigation into the reactivity, deactivation, and in situ regeneration of Pt-based catalysts for the selective reduction of NOx under lean burn conditions. J. Catal. 1999, 182, 234-243. [CrossRef]

143. Tiwari, R.K.; Balagangatharan, B. Experimental Analysis of LNT/DPF after Treatment System on a Passenger Car for Indian Road Condition; SAE Technical Papers; SAE International: Warrendale, PA, USA, 2019.

144. Theis, J.R.; Kim, J.; Cavataio, G. TWC+LNT/SCR Systems for Satisfying Tier 2, Bin 2 Emission Standards on Lean-Burn Gasoline Engines. SAE Int. J. Fuels Lubr. 2015, 8, 474-486. [CrossRef]

145. Goes, J.E.D.A.; Kristoffersson, A.; Olsson, L. Sulfur poisoning effects on modern lean nox trap catalysts components. Catalysts 2019, 9, 492. [CrossRef]

146. Kang, W.; Choi, B.; Jung, S.; Park, S. PM and NOx reduction characteristics of LNT/DPF+SCR/DPF hybrid system. Energy 2018, 143, 439-447. [CrossRef]

147. Demuynck, J.; Bosteels, D.; Bunar, F.; Spitta, J. Diesel Passenger Car with Ultra-low NOx Emissions in Real Driving Conditions. MTZ Worldw. 2020, 81, 40-43. [CrossRef] 